\title{
Dyeing of cotton and silk using vegetable kitchen waste: A step towards sustainability
}

\author{
Riddhi Bhanushali Vallabhij ${ }^{1} \mid$ Vishaka Karnad AshishT ${ }^{2}$
}

1M.Sc. Research Student Department of Textile and Fashion Technology, College of Home Science Nirmala Niketan Affiliated to University of Mumbai, Mumbai, Maharashtra, India

riddhibv21@gmail.com

${ }^{2}$ Assistant Professor Department of Textile and Fashion Technology, College of Home Science Nirmala Niketan Affiliated to University of Mumbai, Mumbai, Maharashtra, India

vishakakarnad@gmail.com

\section{To Cite this Article}

Riddhi Bhanushali Vallabhji and Vishaka Karnad AshishT, "Dyeing of cotton and silk using vegetable kitchen waste: A step towards sustainability", International Journal for Modern Trends in Science and Technology, 6(9S): 214-233, 2020.

\section{Article Info}

Received on 25-August-2020, Revised on 08-September-2020, Accepted on 12-September-2020, Published on 18-September-2020.

\section{ABSTRACT}

Vegetable wastes occur throughout the supply chain. Globally, around 20\% loss occurs at consumer levels, of which post-harvest and food processing level wastages account for $80 \%$ share. Wastes pose environmental threats and call for the development of a model to recycle this unutilized waste in potential avenues. The study focuses on sourcing of vegetable \& fruit kitchen waste and extracts the dyes from waste to create a concrete framework in managing the kitchen waste towards using it for textile dyeing. The study will compare microwave extraction and conventional extraction method (exhaustion) and dyeing processes in terms of depth of shade and hue. The present results have demonstrated that the affinity of vegetable kitchen waste material as a source of natural coloring agents for dyeing proteinic silk fabric is higher than cellulosic cotton fabric by using both conventional and microwave assisted dyeing. Compared to conventional the microwave-assisted extraction and dyeing technique is highly effective in terms of saving the processing time, energy, and resources. Other additional features about microwave is that it is cheaper, more economical, energy saving and thereby eco-friendly. Consumers believed as expressed in the opinion survey that this research idea is excellent and will help in reducing waste.

KEYWORDS: Vegetable Kitchen Waste, Natural Dyeing, Microwave assisted dyeing and Sustainability.

\section{INTRODUCTION}

Kitchen waste is defined as remaining (not eaten) organic matter which is produced in hotels, restaurants and households [3]. Vegetable wastes occur throughout the supply chain. Globally, around $30 \%$ loss occurs at consumer levels, of which post-harvest and food processing level wastages account for $80 \%$ share. $20 \%$ wastage occurs during consumer usage of vegetables in household, canteen, restaurant kitchens [8]. Annually India throws 13,000 crore worth vegetable and fruits due to lack of adequate resources for storage and transport [2]. Wastes pose environmental threats and call for the development of a model to recycle this unutilized waste in potential avenues. This kitchen waste has 
a potential to function as a source of extraction of natural dyes which can be used in textile dyeing.

At present consumption of natural dyes internationally is low compared to synthetic dyes. This may be because of existing limitations and procurement of natural dyes. Because of this demand are shifted to synthetic dyes which are easily available with vibrant shades of colors. However, present focus of dye industry is on resurgence in the interest of eco-friendly dyes. Many research has shown that synthetic dyes release chemicals that areharmful, allergic, carcinogenic and injurious to human health. Synthetic dyes create environmental problems with that disposal of synthetic dyes waste without first processing will pollute the environment [7].

Now a days demand of natural dyes is increasing day by day all over the world. Reason behind these is increased global awareness and environment related consciousness for the use of natural resources for saving earth and environment from pollution and ecological imbalance. Therefore an urge to utilize vast diversity of natural resources of color is increasing. Natural dyes are becoming popular because most of them are biodegradable, eco-friendly, non-toxic and sustainable [7]. In addition natural dyes also function as antibacterial, antioxidant and anti carcinogenic due to the presence of phenolic compounds. By using these resources life on earth can be protected and prolonged [9].

Natural dyes are derived from plants, animals and minerals. There is a wide range of color spectrum available in natural dyeing [10]. But the trade of the natural dyes began to decline due to labour intensive agronomy and time consuming process.However, the extraction of dyes from natural resources is inadequate, slow and require very intensive labour process. Because of tedious extraction and purification procedures makes the natural dyes marketed at very high price which is not affordable for both dyers and consumers. Therefore there is a need to reduce the cost of processing of extraction and dyeing of natural dyes [6]. This can be done using easily available vegetable kitchen waste.

To make the process more eco-friendly, rapid with better results microwave assisted extraction and dyeing can be used. In literature microwave energy has been considered as a clean source of energy and application of natural dyes [10]. Hence there is need of using such kind of technology which will give maximum outcome using minimum resources.
The work is an attempt to study the possibilities of application of few freely available plant/ vegetable components. Most of the coloring matters used will be household vegetable kitchen waste. Hence the cost of dyes will be low. With that coloring matter used are biodegradable and harmless [6]. With that the mordants which are used are also natural. Hence the whole process will be eco-friendly. However the use of microwave can possibly makes the extraction and dyeing process much faster than conventional extraction and dying

\section{process [10].}

Microwave-assisted extraction (MAE) is a green extraction technique which is automated. There are many advantages of MAE techniques such as reduction of the solvent, extraction time and throughput time. MAE is modern and very attractive alternative to conventional methods such as exhaustion and soxhlet method of extraction [5].

The study has undertaken the Microwave assisted dyeing. This process supplements the process and in specific cases totally replace conventional heating system in industry because some systems are very bulky, not easy to operate, can pollute the environment due to harmful emissions of chemicals with that very high energy inefficient. The key feature of microwave heating is that the process is very fast, eliminating the need to heat a container. The advantage of using microwave for industrial purposes are speedy heat transfer, selective volumetric heating, compactness of apparatus, easy and rapid switching on and off and it does not pollute environment as it does not release any harmful products of combustion. Microwave heating allows the choice of processing fluids to use.Microwave heating allows the choice of processing fluids to use. Microwave processing is an inherently dry and fumeless process [4]. There are various advantages of microwave dyeing that it is environmentally friendly process, less power consumption, better dye uptake, quick dyeing compared to conventional dyeing [1]. Microwave dyeing and extraction is encouraging technology innovation extraction and dyeing process performed in the study. This technique is green technique of natural dyeing and extraction process [9].

\section{MATERIALS}

\section{A. Fabric / Substrate}

Kala cotton fabric hand spun, hand-woven was 
bought from Bhujodi, Kutch, Gujarat. The fabric was mercerized and it was ready to dye fabric. The fabric was tested for qualitative tests such as microscopic test, burning test and chemical solubility test to verify fiber content.

Pure silk fabric was bought from local Hindmata cloth market in Dadar, Mumbai, Maharashtra. The fabric was tested for Burning test to verify fiber content.

\section{B. Procedure for Sampling}

Both kala cotton and silk was cut into $14 * 14 \mathrm{~cm}$ weighing $2.35 \mathrm{gm}$. and $0.68 \mathrm{gm}$. respectively.

\section{Dyeing Agents}

Natural kitchen vegetable waste matter was used as natural dye sources. The household vegetable kitchen waste was gathered and used instead being thrown in the wet garbage.

Table 1 Vegetable kitchen waste matters and their colors.

\begin{tabular}{|c|c|c|}
\hline Sr. No. & $\begin{array}{l}\text { Vegetable kitchen } \\
\text { waste matter }\end{array}$ & $\begin{array}{l}\text { Original color of } \\
\text { waste matter }\end{array}$ \\
\hline 1 & Red spinach stems & Maroon/ Beet red \\
\hline 2 & Red apple peels & Red \\
\hline 3 & Green peas pod & Light green \\
\hline $\begin{array}{r}4 \\
+6\end{array}$ & Red carrot peels & $\begin{array}{l}\text { Pinkish red (light } \\
\text { pink) }\end{array}$ \\
\hline 5 & $\begin{array}{c}\text { Dried chick peas } \\
\text { pod }\end{array}$ & Light brown \\
\hline 6 & Fenugreek stems & Green \\
\hline 7 & Tulsi stems & Olive green \\
\hline 8 & Cauliflower leaves & Dark green \\
\hline 9 & Cucumber peels & Whitish light green \\
\hline 10 & Mango peels & Yellow orange \\
\hline 11 & $\begin{array}{l}\text { Roasted chana } \\
\text { peels }\end{array}$ & Dark brown \\
\hline
\end{tabular}

\section{Mordants}

The following mordants were used

\section{Harda / myrobolan \\ 2. Pomegranate rind powder}

\section{E. Equipment/ Instruments}

1. Weighing scale

2. Big vessels for dyeing

3. Beaker

4. Measuring cylinder

5. Stirring glass rod

6. Spoon

7. Burners

8. Electric mixer grinder

9. Household microwave

10. Microwave safe glass bowl

11. Knife

\section{METHODOLOGY}

\section{A. Pilot Study}

- A pilot study was carried out with household vegetable kitchen waste sources (namely cucumber peels, brinjal peels and cauliflower leaves considered as waste) to check the feasibility of dyeing cotton and silk fabrics with conventional method.

- Three different materials to liquor ratio (MLR)s were taken 1:15, 1:20, and 1:30 and were used for extraction and dyeing.

- Extraction was carried out for 30 minutes and 1 hour for $90-110^{\circ} \mathrm{C}$.

- Dyeing was carried out for 1 hour at $90-110^{\circ} \mathrm{C}$ for pre-mordanted samples.

B. Extraction Of Dyes From Household Vegetable Kitchen Waste Sources

1. Aqueous extraction using conventional exhaust method

- All the vegetable wastes were washed with water to remove dirt.

- Perishable vegetable wastes such as Red spinach stems waste, Red apple peels waste, Green peas pod waste, Red carrot peels waste, Fenugreek stem waste, Tulsi stem waste, Cauliflower leaves waste, Cucumber peels waste and Mango peels waste was chopped into small pieces.

- The chopped pieces were ground in an electric mixer using $200 \mathrm{ml}$ of distilled water to make a smooth paste.

- The paste was used directly as the dyeing agent.

- Food waste sources such as Roasted chana peels waste and dried chick peas pod waste was ground in electric mixture to make fine powder.

- The ground powder was used directly as dyeing agent.

- The aqueous extraction was carried out in distilled water keeping material to liquor ratio (MLR) 1:15.

- The paste was added in required amount of water to maintain 1:15 MLR and was boiled at $90^{\circ} \mathrm{C}$ to $100^{\circ} \mathrm{C}$ for 1 hour with constant stirring.

- Finally, the extract was majorly separated from the waste residue.

2. Aqueous microwave-assisted extraction (MAE)

- The initial process of making paste is same 
as 4.3.1-a

- Microwave Assisted Extraction (MAE) was conducted in household microwave oven with model MO 20 GJP 11B (Onida) of 2450 $\mathrm{MHz}$ operation frequency was used with a rated microwave power output of $800 \mathrm{~W}$.

- A microwave safe glass bowl was used as dye vessel containing $200 \mathrm{ml}$ of distilled water (enough to dissolve the paste) and paste of natural vegetable kitchen waste.

- The glass bowl was placed in the centre of the microwave oven, containing a circular, $360^{\circ}$ rotating carousel.

- The extraction was carried out till the temperature reached $100^{\circ} \mathrm{C}$ which required 6 minutes of microwave cooking.

C. Mordanting Of Fabric Samples

1. Mordanting using conventional method

- The cotton and silk fabric samples were mordanted using pre-mordanting technique.

- Harda / myrobolan and Pomegranate rind powder mordants were used with concentration of $15 \%$ on weight of fabric.

- Keeping the MLR 1:20

- The samples were heated in this solution for 30 minutes at $50^{\circ} \mathrm{C}$ to $80^{\circ} \mathrm{C}$ with constant stirring.

2. Mordanting using Microwave

- The cotton and silk fabric samples were mordanted using pre-mordanting technique.

- Harda / myrobolan and Pomegranate rind powder mordants were used with concentration of $15 \%$ on weight of fabric.

- The mordanting was done in a glass bowl containing $200 \mathrm{ml}$ distilled water (enough to immerse the fabric samples) and mordanting agent.

- The mordanting was carried out for 6 minutes in household microwave oven with model MO 20 GJP 11B (Onida) of $2450 \mathrm{MHz}$ operation frequency was used with a rated microwave power output of $800 \mathrm{~W}$.

\section{Dyeing}

1. Conventional exhaust method

- The samples were dyed in extracted solution for $80^{\circ} \mathrm{C}$ to $100^{\circ} \mathrm{C}$ for 1 hour.
- Keeping the MLR 1:20 (distilled water)

- The samples were taken out, washed in tap water at room temperature.

- The samples were cured in oven for 1 minute at $120^{\circ} \mathrm{C}$.

- After that samples were dried in sunlight for 6 hours from 10 am to $4 \mathrm{pm}$.

2. Microwave assisted dyeing (MAD)

- Microwave Assisted Dyeing (MAD) was performed in household microwave oven with model MO 20 GJP 11B (Onida) of 2450 $\mathrm{MHz}$ operation frequency was used with a rated microwave power output of $800 \mathrm{~W}$.

- A microwave safe glass bowl was used as dye vessel for dyeing.

- The glass bowl was situated in the centre of the microwave oven, containing a circular, $360^{\circ}$ rotating carousel.

- The samples were dyed in same extraction solution which was extracted before till the temperature reached $100^{\circ} \mathrm{C}$ which required 6 minutes of microwave cooking.

- The samples were taken out, washed in tap water at room temperature.

- The samples were cured in microwave for 1 minute.

- After that samples were dried in sunlight for 6 hours from 10 am to $4 \mathrm{pm}$.

E. Procedure For Data Collection: Survey

1. Pre-dyeing survey

- This survey was carried out to understand how much vegetable and food waste is produced daily in household kitchen, street food vendors and vegetable markets.

- The survey was also taken to understand what methods were used to discard the waste.

- The other objective of the survey was to understand consumer's preferences in terms of natural dyeing and its awareness.

2. Post-dyeing survey

- This survey was carried out after the samples were dyed with vegetable kitchen waste which is produced daily in household kitchens.

- The objective of survey was to understand the consumers' satisfaction of the dyed samples.

- Consumers were allowed to mark each dyed sample as per the depth of shade and color 
preference.

F. Framework To Manage The Kitchen Waste

- The data was gathered in survey to understand how much vegetable and fruit waste was produced daily in a household kitchen on an average basis, which vegetables and fruits are used frequently, what is the composition of waste, how consumers discard their waste, do they recycle the waste, are they aware of any organization who collects the waste and recycle it, will they like to patronize/support to collect their waste and recycle it, will they like the textile product dyed from the waste provided by them and at what price range and finally all of these will help in reducing the waste; all these data were correlated and consolidated to create a conceptual framework.

\section{RESULTS}

A. Pre- Dyeing Survey

How much vegetable and fruit waste

is produced daily in your kitchen. Marked as ratio of usable vegetable:discarded waste e.g. $100 \%$ usable: $0 \%$ waste

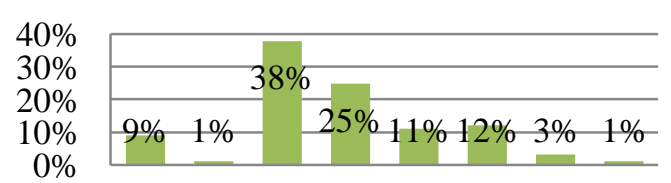

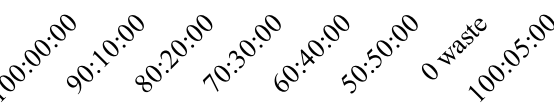

Figure 1(a) How much vegetable and fruit waste is produced daily in consumer's kitchen

The result of survey states that highest amount of waste is produced in the ratio of $\mathbf{8 0} \%$ usable vegetable: $20 \%$ discarded waste.

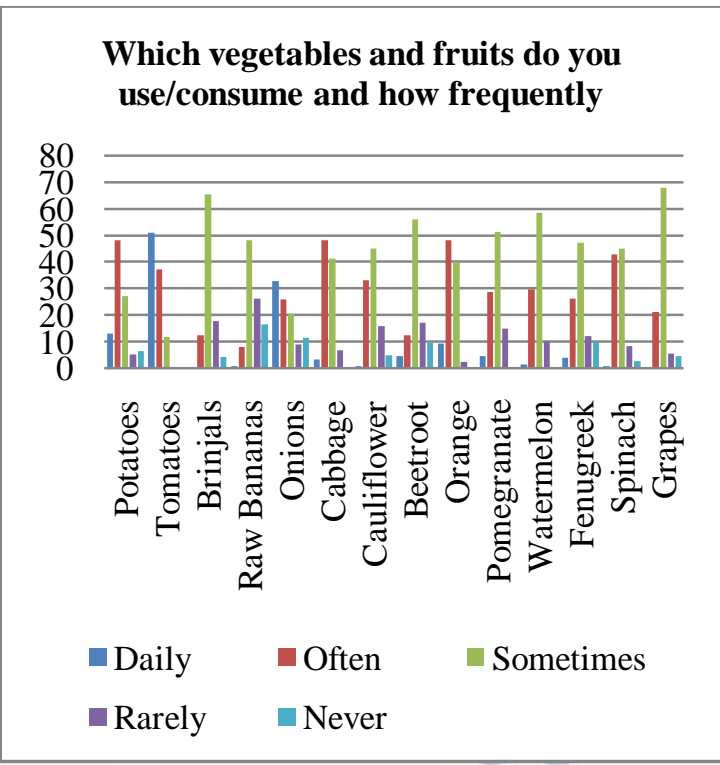

Figure 1(b) Which vegetables and fruits consumers use/consume and how frequently The result of the survey states that onions and tomatoes are used daily; potatoes, cabbage and orange are used often; brinjals, raw bananas, cauliflower, beetroot pomegranate, watermelon, fenugreek, spinach and grapes are used sometimes in household kitchen.

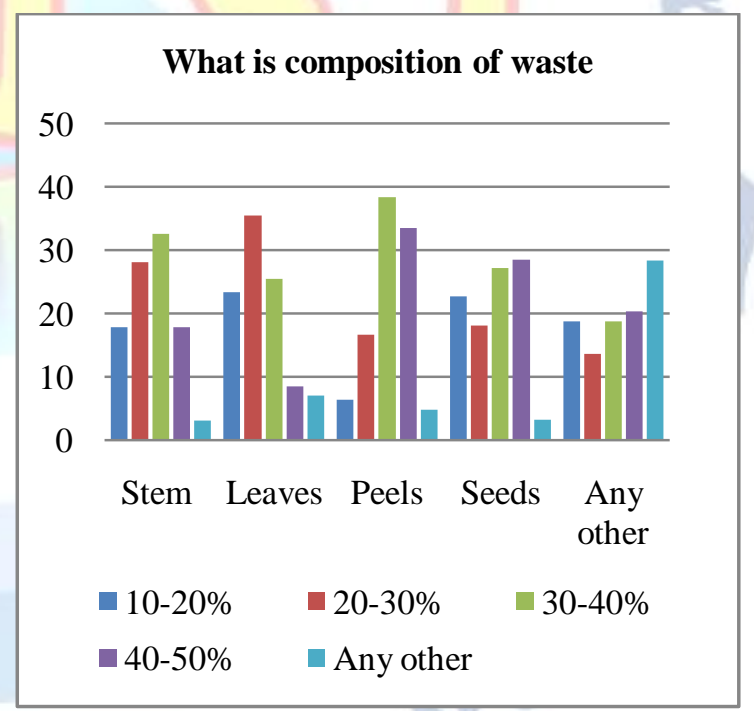

Figure 1 (c) What is composition of waste

The result of the survey states that highest amount of waste component produced is peels followed by seeds, stems and leaves. 


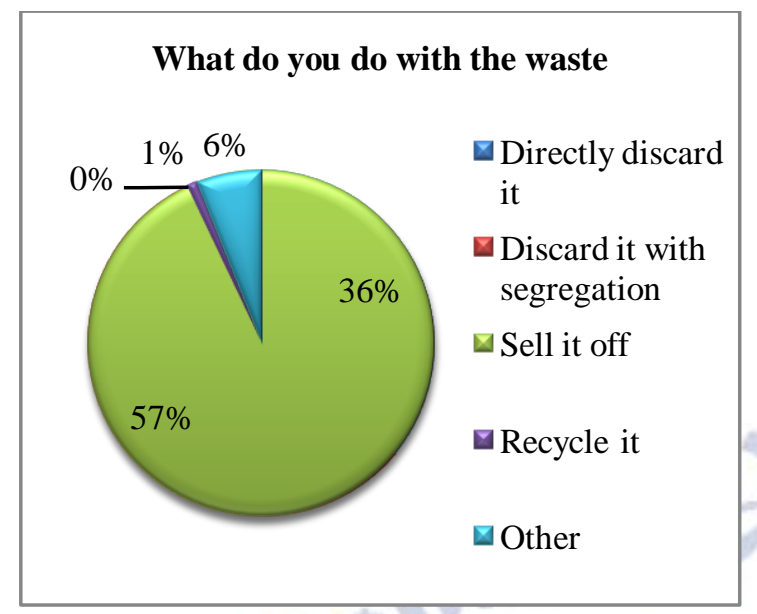

Figure 1(d) What consumers do with the waste

The result of survey states that $\mathbf{5 7 \%}$ of consumers discard the waste by segregating into dry and wet waste while $36 \%$ of consumers discard the waste directly without any segregation and only $1 \%$ of consumers recycle the waste.

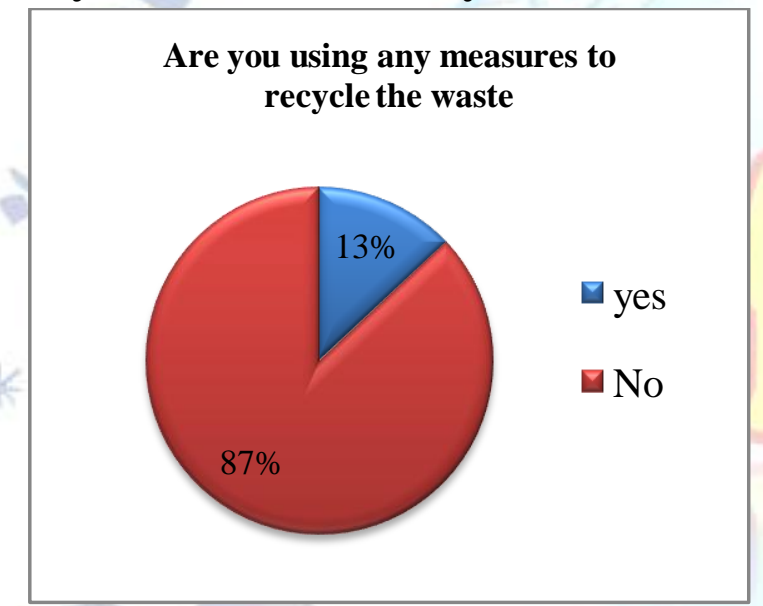

Figure 1(e) Are consumers using any measures to recycle the waste

The result of survey states that $\mathbf{8 7} \%$ of consumers are not recycling the waste and only $13 \%$ of consumers recycling the waste.

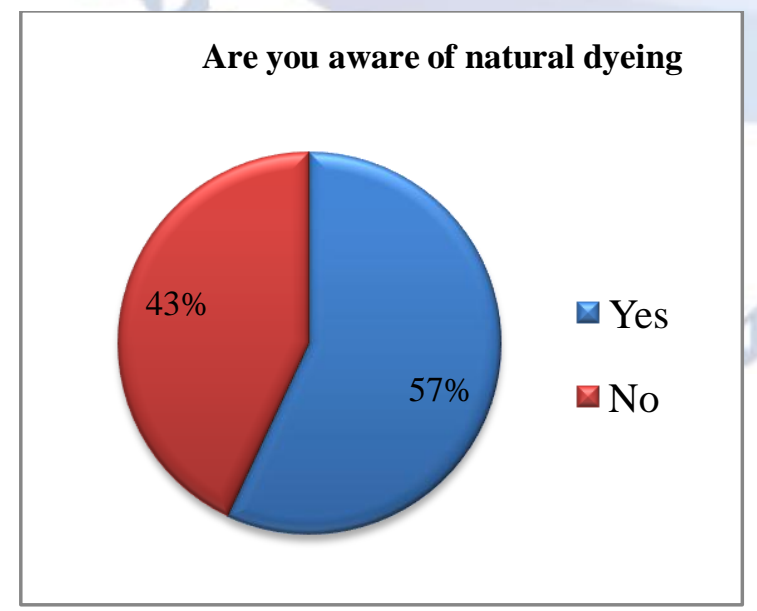

Figure 1(f) Are consumers aware of natural dyeing

The result of the survey states that $\mathbf{5 7 \%}$ of consumers are aware about natural dyeing whereas $\mathbf{4 3} \%$ of consumers are not aware about natural dyeing.

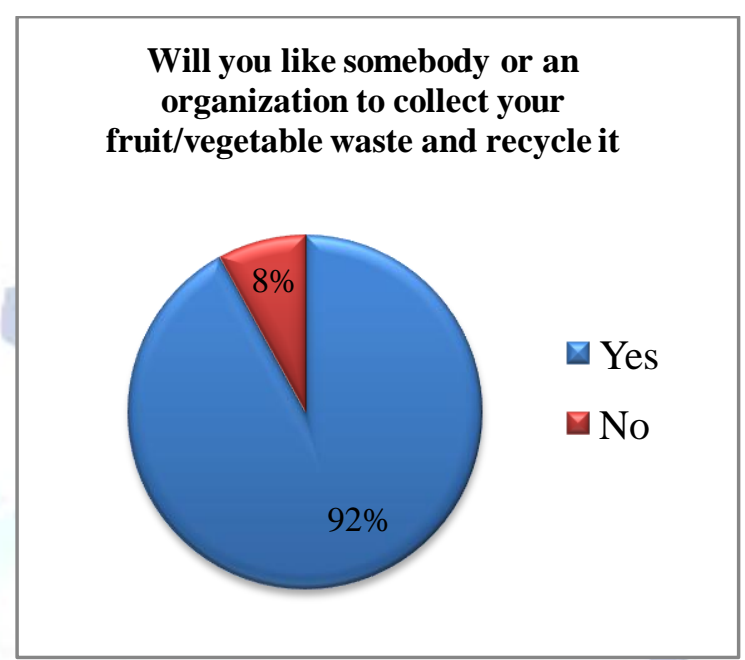

Figure 1(g) Will consumers like somebody or an organization to collect their fruit/vegetable waste and recycle it

The result of survey states that $\mathbf{9 2 \%}$ of consumers are willing to give their kitchen waste for recycling whereas only $\mathbf{8 \%}$ of consumers are not willing to give their kitchen waste for recycling.

Are you aware of any system that collect and recycle the kitchen waste

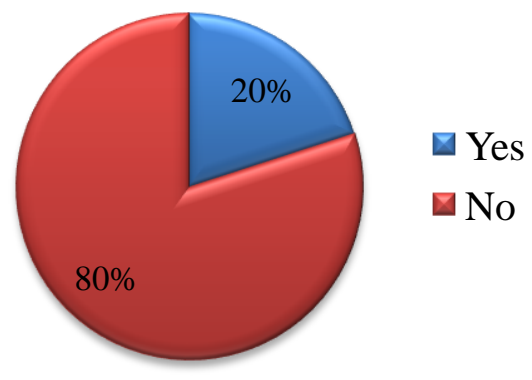

Figure 1(h) Are consumers aware of any systems that collect and recycle the kitchen waste

The result of survey states that $\mathbf{8 0 \%}$ of consumers are not aware about any organization/system that collect and recycle the kitchen waste whereas only $\mathbf{2 0} \%$ of consumers are aware about any organization/system that collect and recycle the kitchen waste. 
Will you like to patronize/support someone who will collect and recycle your kitchen waste

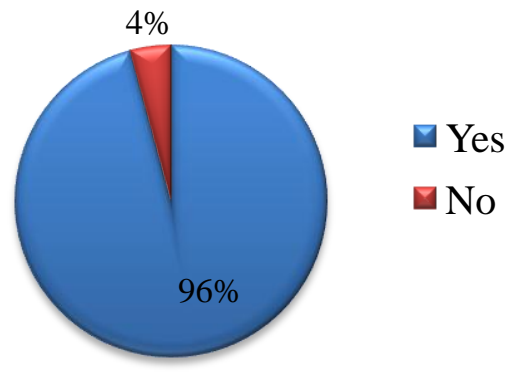

Figure 1(i) Will consumers like to patronize/support someone who will collect and recycle their kitchen waste

The result of the survey states that $96 \%$ of consumers are willing to support whereas only $\mathbf{4 \%}$ of consumers are not willing to support.

If natural dyed materials from the waste you have provided is given to you as table linen or packaging material will you be willing to use such material

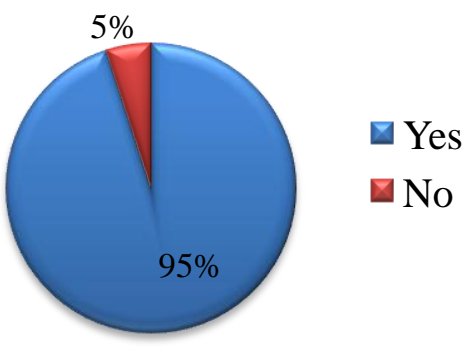

Figure 1(j) If natural dyed materials from the waste consumers have provided is given to them as table linen or packaging material will they be willing to use such material

The result of survey states that $\mathbf{9 5 \%}$ consumers are willing to use the products whereas only $\mathbf{5 \%}$ of consumers are not willing to use the products.
Figure 1(k) Approximate price for which consumers are willing to purchase the dyed products

The result of survey states that $\mathbf{5 3} \%$ of consumers are willing to purchase the product at the price range of $\mathbf{1 5 0 - 2 0 0 ~ R s ; ~} 33 \%$ of consumers are willing to purchase the product at the price range of 250-300 Rs; and 7\% of consumers are willing to purchase the product at the price range of 300-400 Rs.

Do you think this research will help in reducing waste

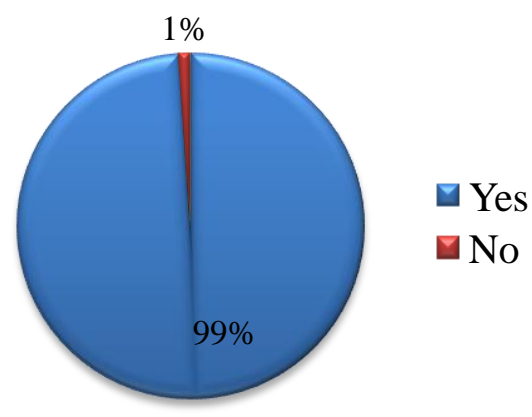

Figure 1(1) Do consumers think this research will help in reducing waste

The result of survey states that $99 \%$ of consumers think that this will help in reducing waste whereas only $\mathbf{1 \%}$ of consumers think that this will not help in reducing waste.

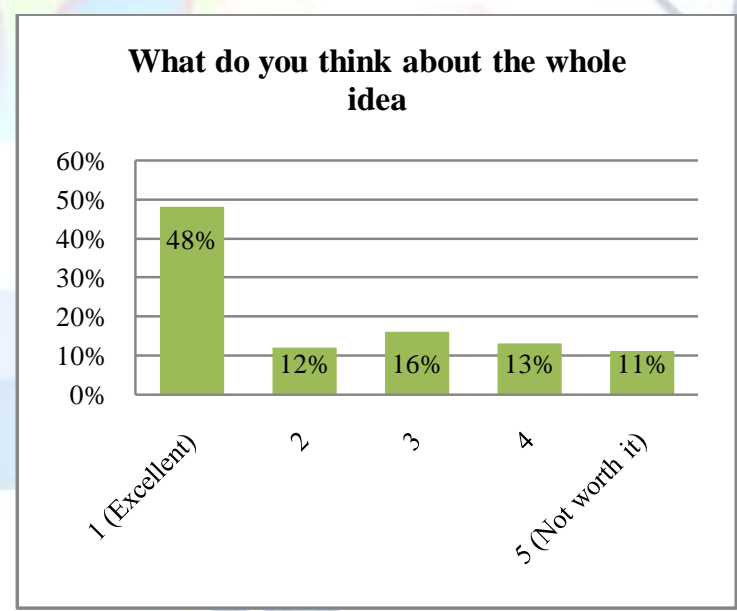

Figure 1(m) What consumers think about the whole idea

The result of the survey states that $\mathbf{4 8 \%}$ of consumers think that this idea is excellent whereas only $\mathbf{1 1} \%$ of consumers think that this idea is not worth it. 


\section{A. Post-Dyeing Survey}

Levels of Satisfaction for Samples Dyed with

Roasted Chana Peels Waste
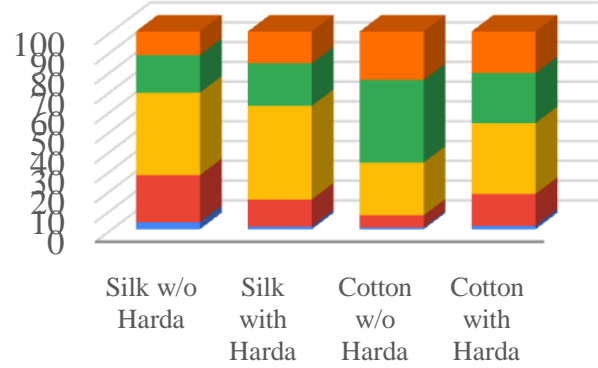

$$
\begin{array}{ll}
\square \text { Not at all satisfied } & \square \text { Slightly satisfied } \\
& \text { Moderately satisfied } \\
\square \text { Very satisfied }
\end{array}
$$

Figure 2(a) Levels of Satisfaction for Samples Dyed with Roasted Chana Peels Waste

With regards to depth of shade and levels of satisfaction the result of the survey, on comparing all the fabric samples indicates that cotton fabric sample was rated the highest in comparison to silk fabric dyed with roasted chana peels waste. Within the silk fabric samples, dyeing with mordant harda was rated higher than silk fabric dyed without mordant harda. While in cotton fabric, samples dyed without mordant harda was rated higher than cotton fabric dyed with mordant harda.

Levels of Satisfaction for Samples Dyed with

Red Spinach Stems Waste

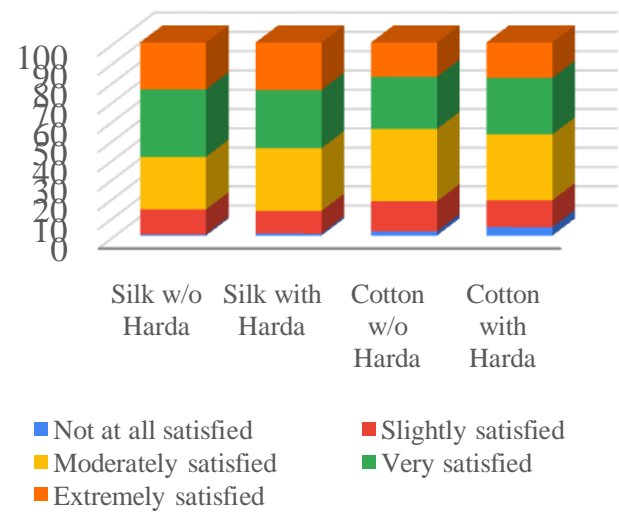

Figure 2(b) Levels of Satisfaction for Samples Dyed with Red Spinach Stems Waste

With regards to depth of shade and levels of satisfaction the result of the survey, on comparing all the fabric samples indicates that silk fabric sample was rated the highest in comparison to cotton fabric dyed with red spinach stems waste. Within the silk fabric samples, dyeing without mordant harda was rated higher than silk fabric dyed with mordant harda. While in cotton fabric, samples dyed with mordant harda was rated higher than cotton fabric dyed without mordant harda.

Levels of Satisfaction for Samples Dyed with Red Apple Peels Waste

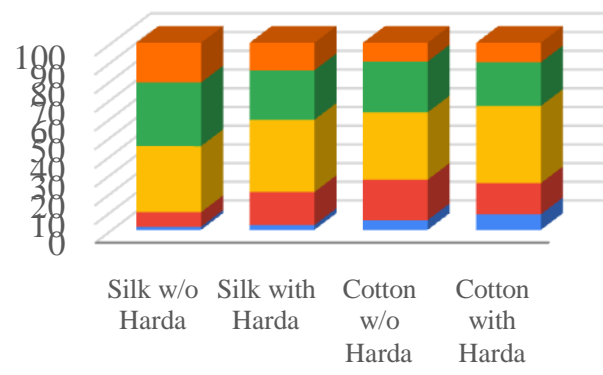

$$
\begin{array}{ll}
\square \text { Not at all satisfied } & \text { Slightly satisfied } \\
\text { Moderately satisfied } & \square \text { Very satisfied } \\
\text { Extremely satisfied } &
\end{array}
$$

\section{Figure 2(c) Levels of Satisfaction for Samples} Dyed with Red Apple Peels Waste

With regards to depth of shade and levels of satisfaction the result of the survey, on comparing all the fabric samples indicates that silk fabric sample was rated the highest in comparison to cotton fabric dyed with red apple peels waste. Within the silk fabric samples, dyeing without mordant harda was rated higher than silk fabric dyed with mordant harda. While in cotton fabric, samples dyed without mordant harda was rated higher than cotton fabric dyed with mordant harda.

\section{Levels of Satisfaction for Samples} Dyed with Green Peas Pod Waste

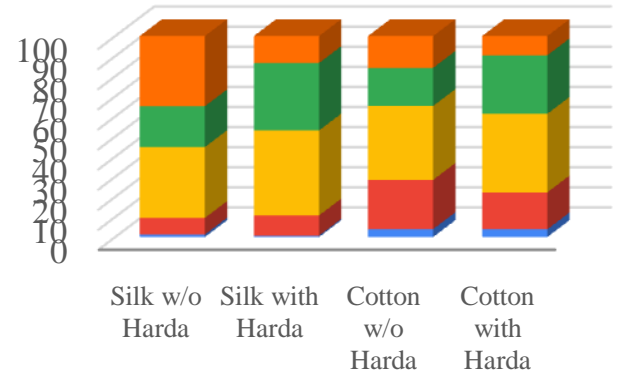

$$
\begin{aligned}
& \square \text { Not at all satisfied } \quad \square \text { Slightly satisfied } \\
& \square \text { Moderately satisfied } \quad \text { Very satisfied } \\
& \square \text { Extremely satisfied }
\end{aligned}
$$

Figure 2(d) Levels of Satisfaction for Samples Dyed with Green Peas Pod Waste

With regards to depth of shade and levels of satisfaction the result of the survey, on comparing 
all the fabric samples indicates that silk fabric sample was rated the highest in comparison to cotton fabric dyed with green peas pod waste. Within the silk fabric samples, dyeing without mordant harda was rated higher than silk fabric dyed with mordant harda. While in cotton fabric, samples dyed with mordant harda was rated higher than cotton fabric dyed without mordant harda.

Levels of Satisfaction for Samples Dyed with

Red Carrot Peels Waste

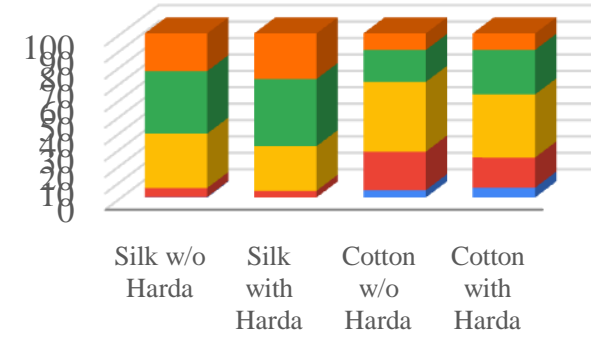

- Not at all satisfied $\quad$ Slightly satisfied - Moderately satisfied $\boldsymbol{\|}$ Very satisfied - Extremely satisfied

Figure 2(e) Levels of Satisfaction for Samples Dyed with Red Carrot Peels Waste

With regards to depth of shade and levels of satisfaction the result of the survey, on comparing all the fabric samples indicates that silk fabric sample was rated the highest in comparison to cotton fabric dyed with red carrot peels waste. Within the silk fabric samples, dyeing with mordant harda was rated higher than silk fabric dyed without mordant harda. While in cotton fabric, samples dyed with mordant harda was rated higher than cotton fabric dyed without mordant harda.

\section{Levels of Satisfaction for Samples Dyed with}

Dried Chick Peas Pod Waste

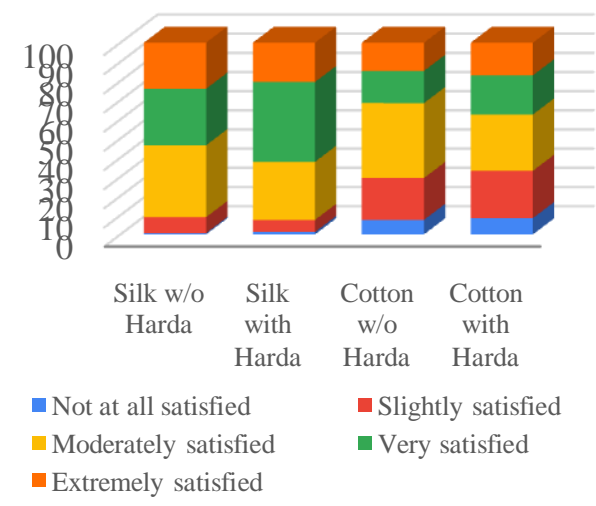

Figure 2(f) Levels of Satisfaction for Samples Dyed with Dried Chick Peas Pod Waste

With regards to depth of shade and levels of satisfaction (shown in Figure 5.2.6) the result of the survey, on comparing all the fabric samples indicates that silk fabric sample was rated the highest in comparison to cotton fabric dyed with dried chick peas pod waste. Within the silk fabric samples, dyeing with mordant harda was rated higher than silk fabric dyed without mordant harda. While in cotton fabric, samples dyed with mordant harda was rated higher than cotton fabric dyed without mordant harda.

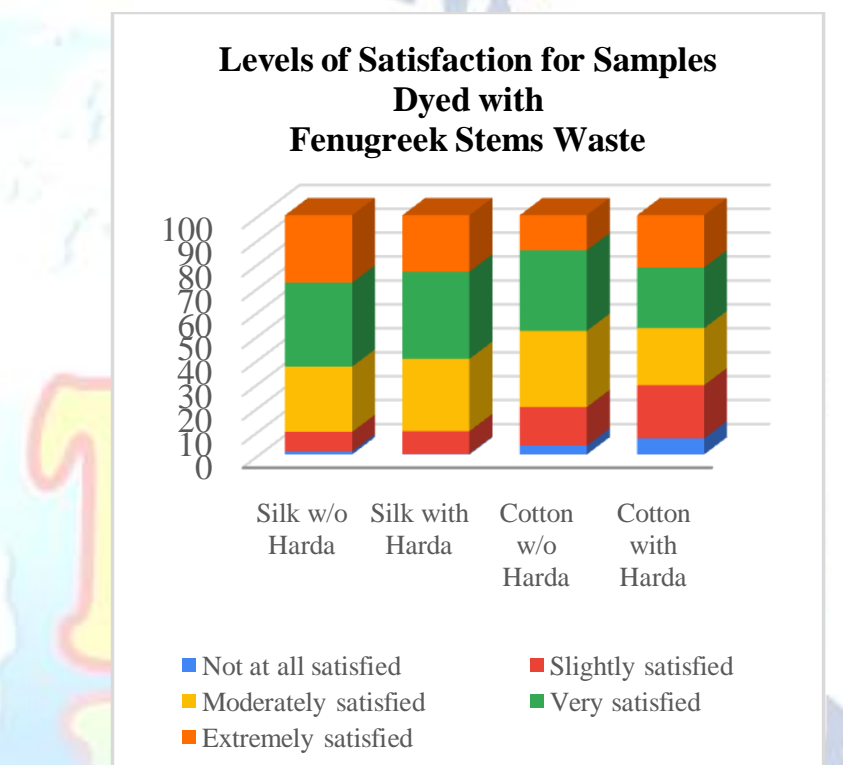

\section{Figure 2(g) Levels of Satisfaction for Samples}

Dyed with Fenugreek Stems Waste

With regards to depth of shade and levels of satisfaction the result of the survey, on comparing all the fabric samples indicates that silk fabric sample was rated the highest in comparison to cotton fabric dyed with fenugreek stems waste. Within the silk fabric samples, dyeing without mordant harda was rated higher than silk fabric dyed with mordant harda. While in cotton fabric, samples dyed with mordant harda was rated higher than cotton fabric dyed without mordant harda. 
Levels of Satisfaction for Samples Dyed with

Tulsi Stems Waste

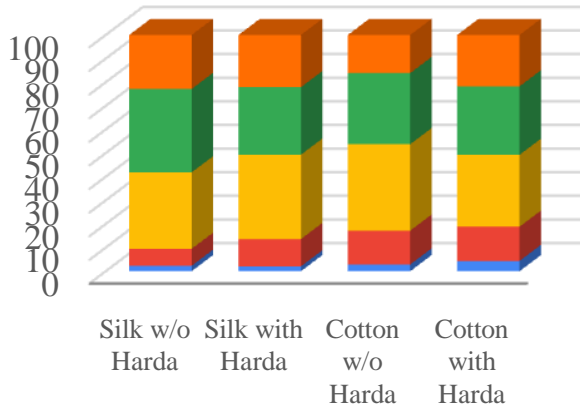

Not at all satisfied

Moderately satisfied

- Extremely satisfied

- Slightly satisfied very satisfied

Figure

2(h) Levels of Satisfaction for Samples Dyed with Tulsi Stems Waste

With regards to depth of shade and levels of satisfaction the result of the survey, on comparing all the fabric samples indicates that silk fabric sample was rated the highest in comparison to cotton fabric dyed with tulsi stems waste. Within the silk fabric samples, dyeing without mordant harda was rated higher than silk fabric dyed with mordant harda. While in cotton fabric, samples dyed with mordant harda was rated higher than cotton fabric dyed without mordant harda.

Levels of Satisfaction for Samples Dyed with

Cauliflower Leaves Waste
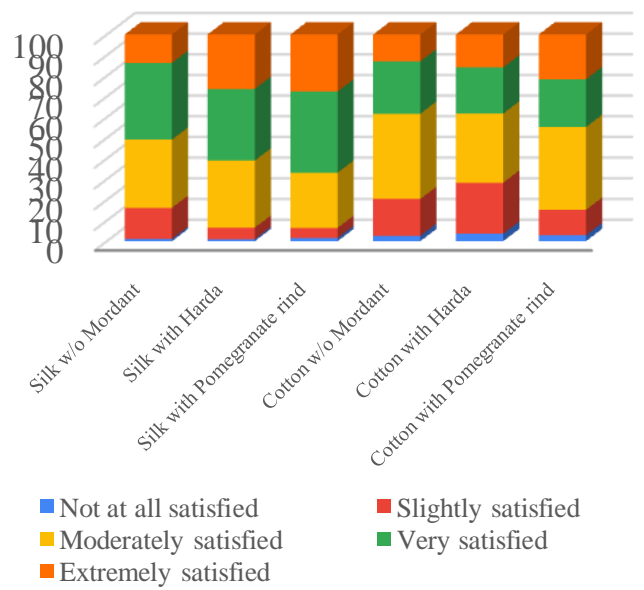

Figure 2(i) Levels of Satisfaction for Samples Dyed with Cauliflower Leaves Waste

With regards to depth of shade and levels of satisfaction the result of the survey, on comparing all the fabric samples indicates that silk fabric sample was rated the highest in comparison to cotton fabric dyed with cauliflower leaves waste. Within the silk fabric samples, dyeing with mordant pomegranate rind was rated higher than silk fabric dyed with mordant harda and without mordant. While in cotton fabric, samples dyed with mordant pomegranate rind was rated higher than cotton fabric dyed with mordant harda and without mordant.

\section{Levels of Satisfaction for Samples Dyed with Cucumber Peels Waste}

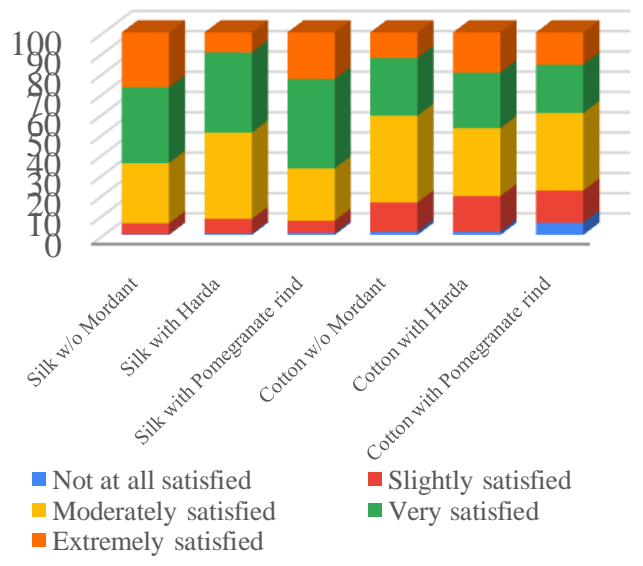

Figure 2(j) Levels of Satisfaction for Samples Dyed with Cucumber Peels Waste

With regards to depth of shade and levels of satisfaction the result of the survey, on comparing all the fabric samples indicates that silk fabric sample was rated the highest in comparison to cotton fabric dyed with cucumber peels waste. Within the silk fabric samples, dyeing with mordant pomegranate rind was rated higher than silk fabric dyed with mordant harda and without mordant. While in cotton fabric, samples dyed with mordant harda was rated higher than cotton fabric dyed with mordant pomegranate rindand without mordant.

Levels of Satisfaction for Samples Dyed with

Mango Peels Waste using Exhaust

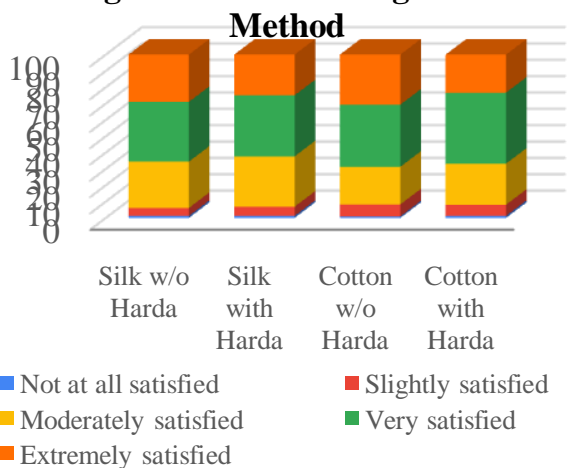

Figure 2(k) Levels of Satisfaction for Samples Dyed with Mango Peels Waste using Exhaust Method

With regards to depth of shade and levels of 
satisfaction the result of the survey, on comparing all the fabric samples indicates that cotton fabric sample was rated the highest in comparison to silk fabric dyed with mango peels waste using exhaust method. Within the silk fabric samples, dyeing without mordant harda was rated higher than silk fabric dyed with mordant harda. While in cotton fabric, samples dyed without mordant harda was rated higher than cotton fabric dyed with mordant harda.

Levels of Satisfaction for Samples Dyed with Mango Peels Waste using Microwave
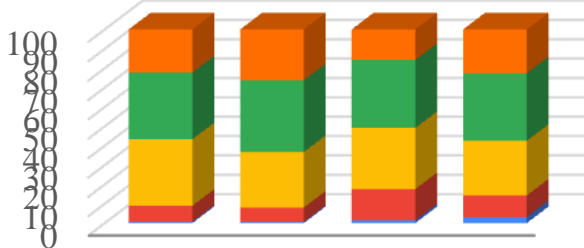

$\begin{array}{cccc}\text { Silk } & \text { Silk } & \text { Cotton } & \text { Cotton } \\ \text { w/o } & \text { with } & \text { w/o } & \text { with } \\ \text { Harda } & \text { Harda } & \text { Harda } & \text { Harda }\end{array}$

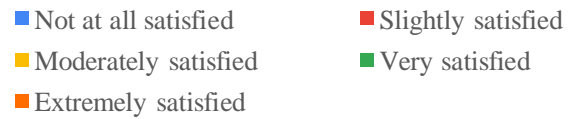

Figure 2(1) Levels of Satisfaction for Samples Dyed with Mango Peels Waste using Microwave

With regards to depth of shade and levels of satisfaction the result of the survey, on comparing all the fabric samples indicates that silk fabric sample was rated the highest in comparison to cotton fabric dyed with mango peels waste using microwave. Within the silk fabric samples, dyeing with mordant harda was rated higher than silk fabric dyed without mordant harda. While in cotton fabric, samples dyed with mordant harda was rated higher than cotton fabric dyed without mordant harda.
FABRIC SAMPLES DYED WITH

" ROASTED CHANA PEELS WASTE "
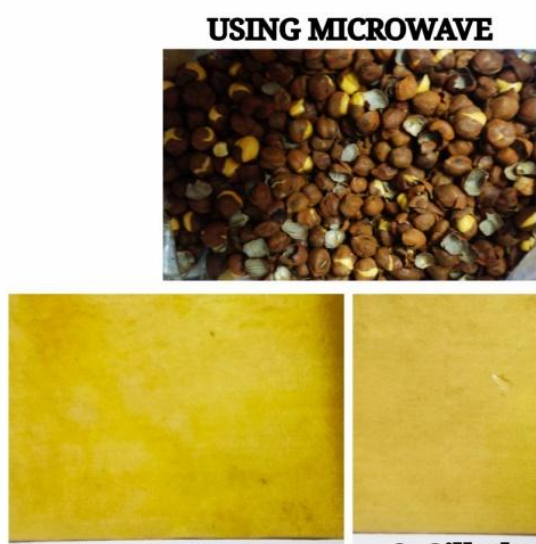

1. Silk dyed without mordant

\section{Silk dyed with mordant Harda}

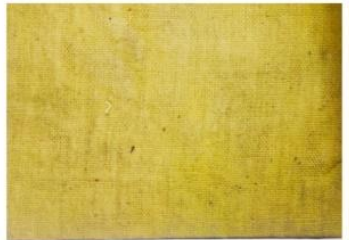

3. Kala cotton dyed without mordant

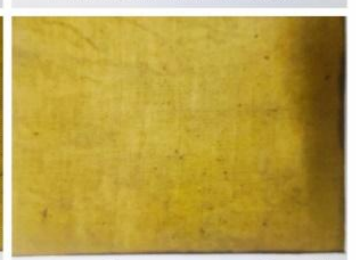

4. Kala cotton dyed with mordant Harda

Figure

3(a) Fabric Samples Dyed with Roasted Chana Peels Waste using Microwave

With regards to depth of shade and levels of satisfaction on comparing all the fabric samples indicates that silk fabric samples showed darker depth of shade in comparison to cotton fabric dyed with roasted chana peels waste using microwave. Within the silk fabric samples, dyeing with mordant harda showed darker depth of shade than silk fabric dyed without mordant harda. While in cotton fabric, samples dyed with mordant harda showed darker depth of shade than cotton fabric dyed without mordant harda

\section{A. Fabric Samples Dyed Using Microwave}


FABRIC SAMPLES DYED WITH

" RED APPLE PEELS WASTE "

USING MICROWAVE
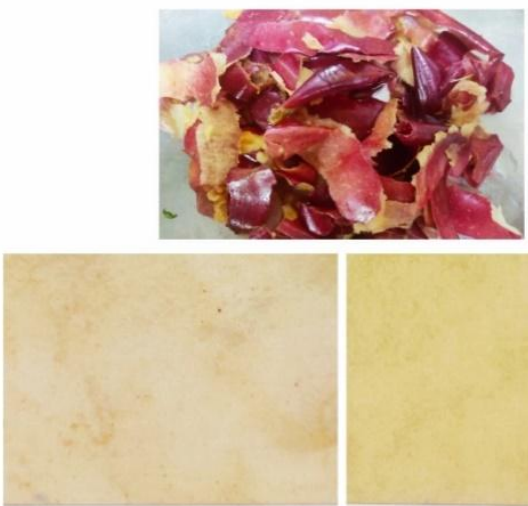

1. Silk dyed without mordant

\section{Silk dyed with mordant Harda}

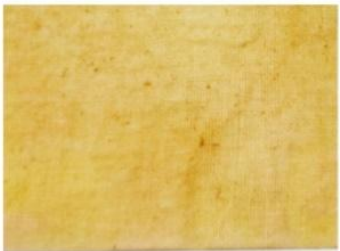
3. Kala cotton dyed
without mordant

\section{Kala cotton dyed} with mordant Harda

Figure

3(b) Fabric Samples Dyed with Red Apple Peels Waste using Microwave

With regards to depth of shade and levels of satisfaction on comparing all the fabric samples indicates that silk samples showed darker depth of shade in comparison to cotton fabric dyed with red apple peels waste using microwave Within the silk fabric samples, dyeing with mordant harda showed darker depth of shade than silk fabric dyed without mordant harda. While in cotton fabric, samples dyed with mordant harda showed darker depth of shade than cotton fabric dyed without mordant harda.
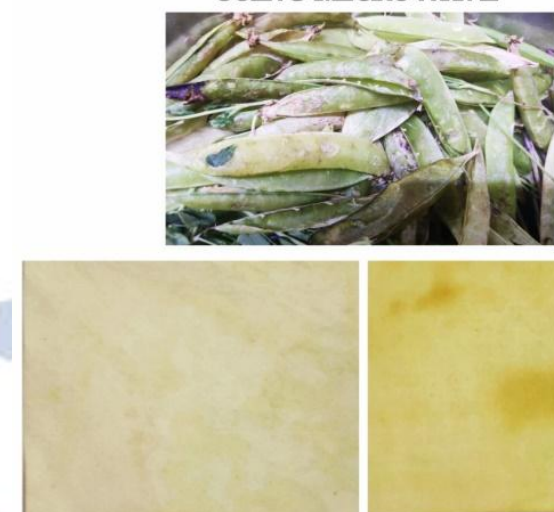

1. Silk dyed without mordant

\section{Silk dyed with mordant Harda}

\section{Kala cotton dyed} without mordant

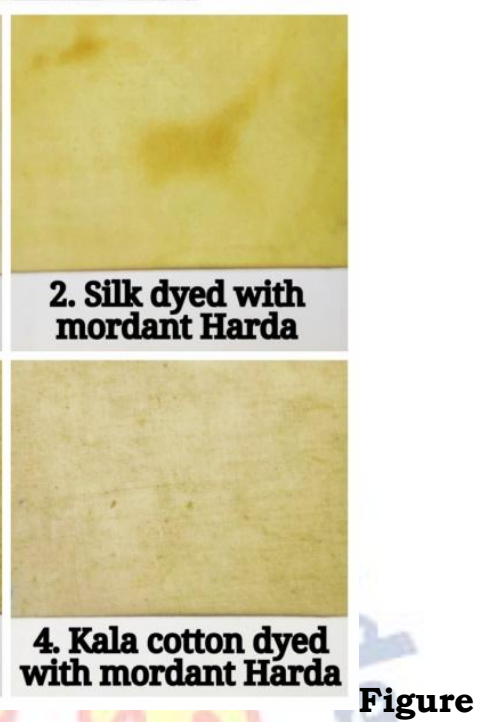

3(c) Fabric Samples Dyed with Green Peas Pod Waste using Microwave

With regards to depth of shade and levels of satisfaction on comparing all the fabric samples indicates that silk fabric samples showed darker depth of shade in comparison to cotton fabric dyed with green peas pod waste using microwave Within the silk fabric samples, dyeing with mordant harda showed darker depth of shade than silk fabric dyed without mordant harda. While in cotton fabric, samples dyed with mordant harda showed darker depth of shade than cotton fabric dyed without mordant harda. 
FABRIC SAMPLES DYED WITH

" RED CARROT PEELS WASTE "

\section{USING MICROWAVE}
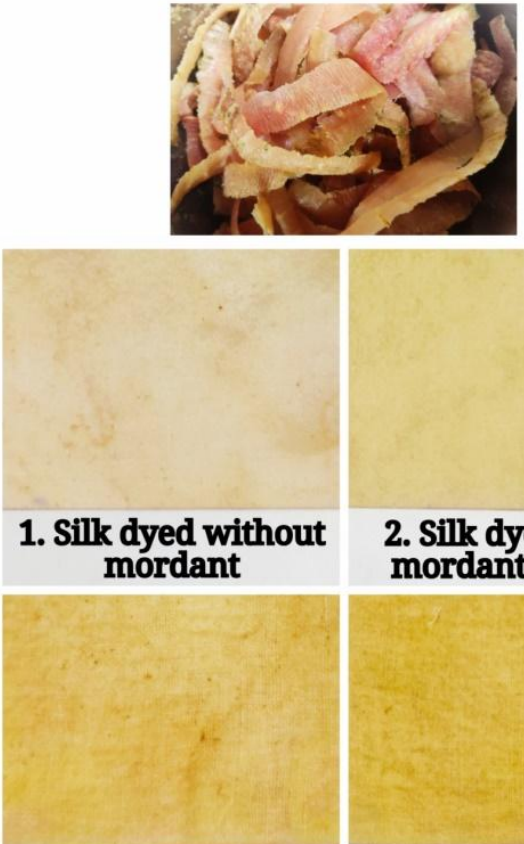

\section{Kala cotton dyed} without mordant

\section{Kala cotton dyed with mordant Harda}

\section{Figure}

3(d) Fabric Samples Dyed with Red Carrot Peels Waste using Microwave

With regards to depth of shade and levels of satisfaction on comparing all the fabric samples indicates that cotton samples showed darker depth of shade in comparison to silk fabric dyed with red carrot peels waste using microwave. Within the silk fabric samples, dyeing with mordant harda showed darker depth of shade than silk fabric dyed without mordant harda. While in cotton fabric, samples dyed with mordant harda showed darker depth of shade than cotton fabric dyed without mordant harda.
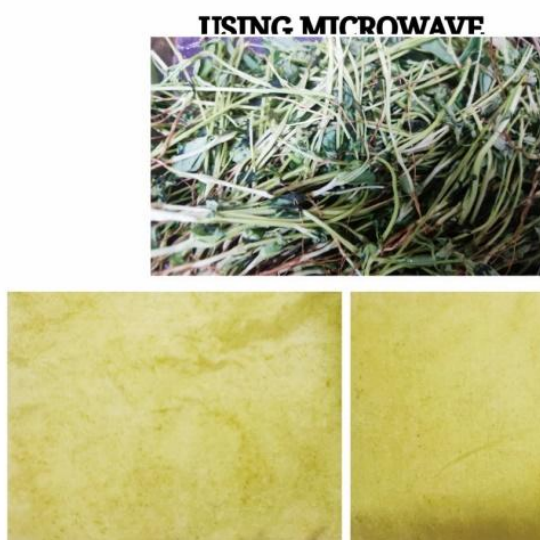

1. Silk dyed without mordant

\section{Silk dyed with} mordant Harda

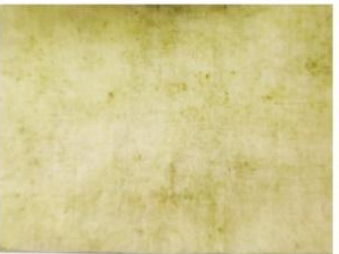

\section{Kala cotton dyed} without mordant

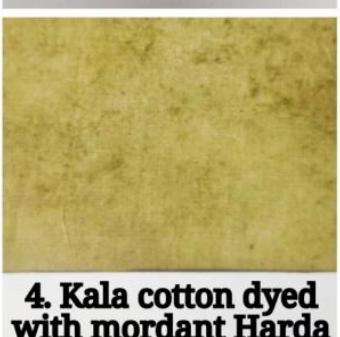

Waste using Microwave

With regards to depth of shade and levels of satisfaction on comparing all the fabric samples indicates that silk samples showed darker depth of shade in comparison to cotton fabric dyed with fenugreek stemswaste using microwave Within the silk fabric samples, dyeing with mordant harda showed darker depth of shade than silk fabric dyed without mordant harda. While in cotton fabric, samples dyed with mordant harda showed darker depth of shade than cotton fabric dyed without mordant harda. 
FABRIC SAMPLES DYED WITH

" TULSI STEMS WASTE "

USING MICROWAVE
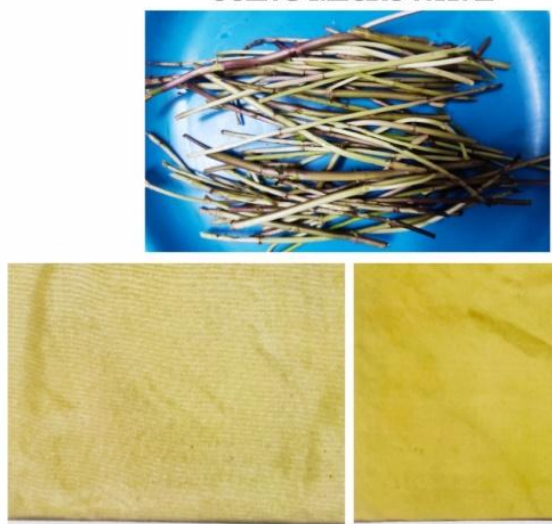

1. Silk dyed without mordant

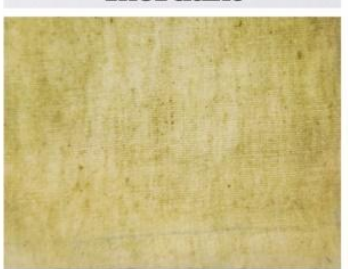

3. Kala cotton dyed without mordant

\section{Kala cotton dyed}

with mordant Harda

Figure

3(f) Fabric Samples Dyed with Tulsi Stems

\section{Waste using Microwave}

With regards to depth of shade and levels of satisfaction on comparing all the fabric samples indicates that silk samples showed darker depth of shade in comparison to cotton fabric dyed with tulsi stems waste using microwave Within the silk fabric samples, dyeing with mordant harda showed darker depth of shade than silk fabric dyed without mordant harda. While in cotton fabric, samples dyed with mordant harda showed darker depth of shade than cotton fabric dyed without mordant harda.

\section{FABRIC SAMPLES DYED WITH}

" CUCUMBER PEELS WASTE "

USING MICROWAVE

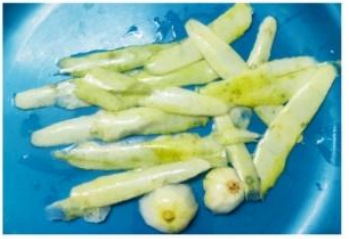

1. Silk dyed without mordant

\section{Silk dyed with} mordant Harda

\section{Kala cotton dyed} without mordant

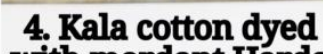

with mordant Harda

Figure

3(g) Fabric Samples Dyed with Cucumber Peels Waste using Microwave

With regards to depth of shade and levels of satisfaction on comparing all the fabric samples indicates that silk samples showed darker depth of shade in comparison to cotton fabric dyed with cucumber peels waste using microwave. Within the silk fabric samples, dyeing with mordant harda showed darker depth of shade than silk fabric dyed without mordant harda. While in cotton fabric, samples dyed with mordant harda showed darker depth of shade than cotton fabric dyed without mordant harda.

\section{B. Comparison Of Color Of Extracted Liquor}

Table 2 Comparison of color of extracted

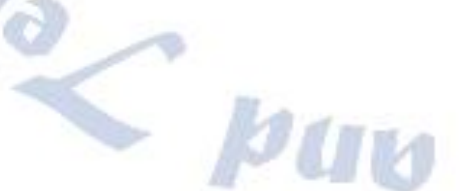
liquor.

\begin{tabular}{|r|c|c|c|}
\hline Sr & $\begin{array}{c}\text { Vegetable } \\
\text { kitchen } \\
\text { No }\end{array}$ & $\begin{array}{c}\text { Conventi } \\
\text { onal } \\
\text { waste } \\
\text { matter } \\
\text { (exhaust) } \\
\text { used as } \\
\text { dye } \\
\text { extractio } \\
\text { source }\end{array}$ & $\begin{array}{c}\text { Microwave } \\
\text { extraction }\end{array}$ \\
\hline 1 & $\begin{array}{c}\text { n } \\
\text { Mango } \\
\text { peels }\end{array}$ & Orange & \\
\hline
\end{tabular}




\begin{tabular}{|r|c|c|c|}
\hline 2 & $\begin{array}{c}\text { Roasted } \\
\text { chana } \\
\text { peels }\end{array}$ & $\begin{array}{c}\text { Dark } \\
\text { brown }\end{array}$ & Dark brown \\
\hline 3 & $\begin{array}{c}\text { Red apple } \\
\text { peels }\end{array}$ & Brown & $\begin{array}{c}\text { Reddish } \\
\text { brown }\end{array}$ \\
\hline 4 & $\begin{array}{c}\text { Green peas } \\
\text { pod }\end{array}$ & $\begin{array}{c}\text { Yellowish } \\
\text { green }\end{array}$ & Light Green \\
\hline 5 & $\begin{array}{c}\text { Red carrot } \\
\text { peels }\end{array}$ & $\begin{array}{c}\text { Reddish } \\
\text { brown }\end{array}$ & Oranges red \\
\hline 6 & $\begin{array}{c}\text { Fenugreek } \\
\text { stems }\end{array}$ & $\begin{array}{c}\text { Dark } \\
\text { green }\end{array}$ & Green \\
\hline 7 & $\begin{array}{c}\text { Tulsi } \\
\text { stems }\end{array}$ & $\begin{array}{c}\text { Dark } \\
\text { green }\end{array}$ & Olive green \\
\hline 8 & $\begin{array}{c}\text { Cucumber } \\
\text { peels }\end{array}$ & $\begin{array}{c}\text { Light } \\
\text { green }\end{array}$ & Light green \\
\hline
\end{tabular}

extraction of vegetable matter using conventional extraction method has shown that most of the extracted vegetable matter color is changing from the original color of vegetable matter to yellowish green, brown and dark green where as in microwave extraction method color of extraction is similar to the original color of vegetable matter in most of the cases.

C. Comparison Of Dyed Samples In Relation To Depth Of Shade

(In terms of dark, light or similar)

1. Silk

From the table it is observed that color of

Table 3 Comparison of dyed silk samples in relation to depth of shade.

\begin{tabular}{|c|c|c|c|c|c|}
\hline Sr. & $\begin{array}{c}\text { Vegetable } \\
\text { kitchen } \\
\text { waste } \\
\text { matter } \\
\text { used as dye } \\
\text { source }\end{array}$ & $\begin{array}{c}\text { Fabric samples } \\
\text { dyed without } \\
\text { mordant using } \\
\text { conventional } \\
\text { (exhaust) } \\
\text { dyeing method }\end{array}$ & $\begin{array}{c}\text { Fabric samples } \\
\text { dyed without } \\
\text { mordant using } \\
\text { microwave } \\
\text { method }\end{array}$ & $\begin{array}{c}\text { Fabric samples } \\
\text { dyed with } \\
\text { mordant using } \\
\text { conventional } \\
\text { (exhaust) } \\
\text { dyeing method }\end{array}$ & $\begin{array}{c}\text { Fabric } \\
\text { samples dyed } \\
\text { with mordant } \\
\text { using } \\
\text { microwave } \\
\text { method }\end{array}$ \\
\hline 1 & Mango peels & $\begin{array}{c}\text { Darker than } \\
\text { microwave }\end{array}$ & $\begin{array}{c}\text { Lighter than } \\
\text { conventional }\end{array}$ & $\begin{array}{c}\text { Darker than } \\
\text { microwave }\end{array}$ & $\begin{array}{c}\text { Lighter than } \\
\text { conventional }\end{array}$ \\
\hline 2 & $\begin{array}{c}\text { Roasted } \\
\text { chana peels }\end{array}$ & $\begin{array}{c}\text { Lighter than } \\
\text { microwave }\end{array}$ & $\begin{array}{c}\text { Darker than } \\
\text { conventional }\end{array}$ & $\begin{array}{c}\text { Both are } \\
\text { similar }\end{array}$ & $\begin{array}{c}\text { Both are } \\
\text { similar }\end{array}$ \\
\hline 3 & $\begin{array}{c}\text { Red apple } \\
\text { peels }\end{array}$ & $\begin{array}{c}\text { Darker than } \\
\text { microwave }\end{array}$ & $\begin{array}{c}\text { Lighter than } \\
\text { conventional }\end{array}$ & $\begin{array}{c}\text { Darker than } \\
\text { microwave }\end{array}$ & $\begin{array}{c}\text { Lighter than } \\
\text { conventional }\end{array}$ \\
\hline 4 & $\begin{array}{c}\text { Green peas } \\
\text { pod }\end{array}$ & $\begin{array}{c}\text { Both are similar } \\
\text { peels }\end{array}$ & $\begin{array}{c}\text { Both are } \\
\text { similar }\end{array}$ & $\begin{array}{c}\text { Lighter than } \\
\text { microwave }\end{array}$ & $\begin{array}{c}\text { Darker than } \\
\text { conventional }\end{array}$ \\
\hline 6 & $\begin{array}{c}\text { Fenugreek } \\
\text { stems }\end{array}$ & Both are same & Both are same & $\begin{array}{c}\text { Both are } \\
\text { similar }\end{array}$ & $\begin{array}{c}\text { Both are } \\
\text { similar }\end{array}$ \\
\hline 7 & $\begin{array}{c}\text { Tulsi } \\
\text { stems }\end{array}$ & $\begin{array}{c}\text { Darker than } \\
\text { microwave }\end{array}$ & $\begin{array}{c}\text { Lighter than } \\
\text { conventional }\end{array}$ & $\begin{array}{c}\text { Darker than } \\
\text { microwave }\end{array}$ & $\begin{array}{c}\text { Lighter than } \\
\text { conventional }\end{array}$ \\
\hline 8 & $\begin{array}{c}\text { Cucumbe } \\
\text { r peels }\end{array}$ & $\begin{array}{c}\text { Darker than } \\
\text { microwave }\end{array}$ & $\begin{array}{c}\text { Lighter than } \\
\text { conventional }\end{array}$ & $\begin{array}{c}\text { Darker than } \\
\text { microwave }\end{array}$ & $\begin{array}{c}\text { Lighter than } \\
\text { conventional }\end{array}$ \\
\hline
\end{tabular}

From the table it is observed that silk fabric samples dyed using vegetable kitchen waste matter without using mordant by conventional (exhaust) method has given darker depthof shade with compare to silk fabric samples dyed using microwave method whereas silk fabric samples dyed using vegetable kitchen waste matter with mordant harda by conventional (exhaust) method has given darker depth of shade with compare to silk fabric samples dyed using microwave method with mordant harda.

1. Kala cotton

Table 4 Comparison of dyed cotton samples in relation to depth of shade. 


\begin{tabular}{|c|c|c|c|c|c|}
\hline $\begin{array}{l}\text { Sr. } \\
\text { No. }\end{array}$ & $\begin{array}{l}\text { Vegetable } \\
\text { kitchen } \\
\text { waste } \\
\text { matter } \\
\text { used as dye } \\
\text { source }\end{array}$ & $\begin{array}{c}\text { Fabric } \\
\text { samples dyed } \\
\text { without } \\
\text { mordant using } \\
\text { conventional } \\
\text { (exhaust) } \\
\text { dyeing method }\end{array}$ & $\begin{array}{c}\text { Fabric } \\
\text { samples dyed } \\
\text { without } \\
\text { mordant using } \\
\text { microwave } \\
\text { method }\end{array}$ & $\begin{array}{c}\text { Fabric } \\
\text { samples dyed } \\
\text { with mordant } \\
\text { using } \\
\text { conventional } \\
\text { (exhaust) } \\
\text { dyeing method }\end{array}$ & $\begin{array}{c}\text { Fabric } \\
\text { samples dyed } \\
\text { with mordant } \\
\text { using } \\
\text { microwave } \\
\text { method }\end{array}$ \\
\hline 1 & $\begin{array}{l}\text { Mango } \\
\text { peels }\end{array}$ & $\begin{array}{l}\text { Darker than } \\
\text { microwave }\end{array}$ & $\begin{array}{l}\text { Lighter than } \\
\text { conventional }\end{array}$ & $\begin{array}{l}\text { Darker than } \\
\text { microwave }\end{array}$ & $\begin{array}{l}\text { Lighter than } \\
\text { conventional }\end{array}$ \\
\hline 2 & $\begin{array}{c}\text { Roasted } \\
\text { chana peels }\end{array}$ & $\begin{array}{l}\text { Lighter than } \\
\text { microwave }\end{array}$ & $\begin{array}{c}\text { Darker than } \\
\text { conventional }\end{array}$ & $\begin{array}{l}\text { Lighter } r \text { than } \\
\text { microwave }\end{array}$ & $\begin{array}{c}\text { Darker than } \\
\text { conventional }\end{array}$ \\
\hline 3 & $\begin{array}{l}\text { Red apple } \\
\text { peels }\end{array}$ & $\begin{array}{l}\text { Darker than } \\
\text { microwave }\end{array}$ & $\begin{array}{l}\text { Lighter than } \\
\text { conventional }\end{array}$ & $\begin{array}{l}\text { Darker than } \\
\text { microwave }\end{array}$ & $\begin{array}{l}\text { Lighter than } \\
\text { conventional }\end{array}$ \\
\hline 4 & $\begin{array}{c}\text { Green } \\
\text { peas pod }\end{array}$ & $\begin{array}{l}\text { Lighter } r \text { than } \\
\text { microwave }\end{array}$ & $\begin{array}{c}\text { Darker than } \\
\text { conventional }\end{array}$ & $\begin{array}{l}\text { Lighter than } \\
\text { microwave }\end{array}$ & $\begin{array}{l}\text { Darker than } \\
\text { conventional }\end{array}$ \\
\hline 5 & $\begin{array}{c}\text { Red carrot } \\
\text { peels }\end{array}$ & $\begin{array}{l}\text { Darker than } \\
\text { microwave }\end{array}$ & $\begin{array}{l}\text { Lighter than } \\
\text { conventional }\end{array}$ & $\begin{array}{l}\text { Lighter than } \\
\text { microwave }\end{array}$ & $\begin{array}{c}\text { Darker than } \\
\text { conventional }\end{array}$ \\
\hline 6 & $\begin{array}{l}\text { Fenugree } \\
\mathrm{k} \text { stems }\end{array}$ & $\begin{array}{l}\text { Lighter than } \\
\text { microwave }\end{array}$ & $\begin{array}{l}\text { Darker than } \\
\text { conventional }\end{array}$ & $\begin{array}{l}\text { Lighter than } \\
\text { microwave }\end{array}$ & $\begin{array}{l}\text { Darker than } \\
\text { conventional }\end{array}$ \\
\hline 7 & $\begin{array}{c}\text { Tulsi } \\
\text { stems }\end{array}$ & $\begin{array}{l}\text { Darker than } \\
\text { microwave }\end{array}$ & $\begin{array}{l}\text { Lighter than } \\
\text { conventional }\end{array}$ & $\begin{array}{l}\text { Darker than } \\
\text { microwave }\end{array}$ & $\begin{array}{l}\text { Lighter than } \\
\text { conventional }\end{array}$ \\
\hline 8 & $\begin{array}{l}\text { Cucumbe } \\
\text { r peels }\end{array}$ & $\begin{array}{l}\text { Darker than } \\
\text { microwave }\end{array}$ & $\begin{array}{l}\text { Lighter than } \\
\text { conventional }\end{array}$ & $\begin{array}{l}\text { Both are } \\
\text { similar }\end{array}$ & $\begin{array}{l}\text { Both are } \\
\text { similar }\end{array}$ \\
\hline
\end{tabular}

From the table it is observed that cotton fabric samples dyed using vegetable kitchen waste matter without using mordant by conventional (exhaust) method has given darker depthof shade with compare to microwave method whereas cotton fabric samples dyed using vegetable kitchen waste matter with mordant harda by conventional (exhaust) method has given darker depth of shade with compare microwave method with mordant harda.

\section{A. Comparison Of Dyed Samples In Relation To Hue Comparison To Original Color Of Vegetable Waste} Matters

(In terms of same, different or similar)

Silk

Table 5 Comparison of silk dyed samples in relation to hue comparison to original color of vegetable waste matters.

\begin{tabular}{|c|c|c|c|c|c|c|}
\hline $\begin{array}{c}\text { Sr. } \\
\text { No. }\end{array}$ & $\begin{array}{c}\text { Vegetable } \\
\text { kitchen } \\
\text { waste } \\
\text { matter used } \\
\text { as dye } \\
\text { source }\end{array}$ & $\begin{array}{c}\text { Original } \\
\text { color of } \\
\text { vegetable } \\
\text { waste } \\
\text { matter }\end{array}$ & $\begin{array}{c}\text { Fabric } \\
\text { samples } \\
\text { dyed without } \\
\text { mordant } \\
\text { using } \\
\text { conventional } \\
\text { (exhaust) } \\
\text { dyeing } \\
\text { method }\end{array}$ & $\begin{array}{c}\text { Fabric } \\
\text { samples } \\
\text { dyed } \\
\text { without } \\
\text { mordant } \\
\text { using } \\
\text { microwave } \\
\text { method }\end{array}$ & $\begin{array}{c}\text { Fabric } \\
\text { samples } \\
\text { dyed with } \\
\text { mordant } \\
\text { using } \\
\text { conventional } \\
\text { (exhaust) } \\
\text { dyeing } \\
\text { method }\end{array}$ & $\begin{array}{c}\text { Fabric } \\
\text { samples } \\
\text { dyed with } \\
\text { mordant } \\
\text { using } \\
\text { microwave } \\
\text { method }\end{array}$ \\
\hline 1 & $\begin{array}{c}\text { Mango } \\
\text { peels }\end{array}$ & $\begin{array}{c}\text { Yellow } \\
\text { orange }\end{array}$ & $\begin{array}{c}\text { Similar } \\
\text { (brownish } \\
\text { orange) }\end{array}$ & $\begin{array}{c}\text { Same } \\
\text { (Yellow } \\
\text { orange) }\end{array}$ & $\begin{array}{c}\text { Similar } \\
\text { (brownish } \\
\text { orange) }\end{array}$ & $\begin{array}{c}\text { Same } \\
\text { (Yellow } \\
\text { orange) }\end{array}$ \\
\hline 2 & $\begin{array}{c}\text { Roasted } \\
\text { chana peels }\end{array}$ & $\begin{array}{c}\text { Dark } \\
\text { brown }\end{array}$ & $\begin{array}{c}\text { Similar } \\
\text { (brown) }\end{array}$ & $\begin{array}{c}\text { Same } \\
\text { (dark } \\
\text { brown) }\end{array}$ & $\begin{array}{c}\text { Same } \\
\text { (dark } \\
\text { brown) }\end{array}$ & $\begin{array}{c}\text { Same } \\
\text { (dark } \\
\text { brown) }\end{array}$ \\
\hline 3 & Red apple & Red & Different & Different & Different & Different \\
\hline
\end{tabular}




\begin{tabular}{|c|c|c|c|c|c|c|}
\hline & peels & & (brown) & $\begin{array}{l}\text { (light } \\
\text { brown) }\end{array}$ & (brown) & $\begin{array}{r}\text { (light } \\
\text { brown) }\end{array}$ \\
\hline 4 & $\begin{array}{c}\text { Green } \\
\text { peas pod }\end{array}$ & $\begin{array}{l}\text { Light } \\
\text { green }\end{array}$ & $\begin{array}{l}\text { Different } \\
\text { (yellow) }\end{array}$ & $\begin{array}{l}\text { Different } \\
\text { (yellow) }\end{array}$ & $\begin{array}{l}\text { Different } \\
\text { (light } \\
\text { golden } \\
\text { brown) }\end{array}$ & $\begin{array}{l}\text { Same } \\
\text { (light } \\
\text { green) }\end{array}$ \\
\hline 5 & $\begin{array}{l}\text { Red carrot } \\
\text { peels }\end{array}$ & $\begin{array}{l}\text { Pinkish } \\
\text { red }\end{array}$ & $\begin{array}{l}\text { Different } \\
\text { (golden } \\
\text { brown) }\end{array}$ & $\begin{array}{l}\text { Similar } \\
\text { (light } \\
\text { orange) }\end{array}$ & $\begin{array}{l}\text { Different } \\
\text { (golden } \\
\text { brown) }\end{array}$ & $\begin{array}{l}\text { Similar } \\
\text { (orange) }\end{array}$ \\
\hline 6 & $\begin{array}{l}\text { Fenugreek } \\
\text { stems }\end{array}$ & Green & $\begin{array}{c}\text { Similar } \\
\text { (yellowish } \\
\text { green) }\end{array}$ & $\begin{array}{l}\text { Similar } \\
\text { (yellowish } \\
\text { green) }\end{array}$ & $\begin{array}{l}\text { Similar } \\
\text { (yellowish } \\
\text { green) }\end{array}$ & $\begin{array}{l}\text { Similar } \\
\text { (yellowis } \\
\text { h green) }\end{array}$ \\
\hline 7 & $\begin{array}{c}\text { Tulsi } \\
\text { stems }\end{array}$ & $\begin{array}{l}\text { Olive } \\
\text { green }\end{array}$ & $\begin{array}{c}\text { Same } \\
\text { (olive green) }\end{array}$ & $\begin{array}{l}\text { Same } \\
\text { (olive } \\
\text { green) }\end{array}$ & $\begin{array}{l}\text { Different } \\
\text { (golden } \\
\text { brown) }\end{array}$ & $\begin{array}{l}\text { Same } \\
\text { (olive } \\
\text { green) }\end{array}$ \\
\hline 8 & $\begin{array}{l}\text { Cucumber } \\
\text { peels }\end{array}$ & $\begin{array}{l}\text { Whitish } \\
\text { light green }\end{array}$ & $\begin{array}{c}\text { Similar } \\
\text { (light green) }\end{array}$ & $\begin{array}{c}\text { Same } \\
\text { (Whitish } \\
\text { light green) }\end{array}$ & $\begin{array}{c}\text { Different } \\
\text { (light } \\
\text { golden } \\
\text { brown) }\end{array}$ & $\begin{array}{l}\text { Similar } \\
\text { (light } \\
\text { green) }\end{array}$ \\
\hline
\end{tabular}

From the table it is observed that silk fabric samples dyed using vegetable kitchen waste matter with andwithout using mordant harda by microwave method has given same color hue with compare to original hue of vegetable matter conventional (exhaust) method with andwithout using mordant harda has given different color hue with compare to original hue of vegetable matter.

Kala cotton

Table 6 Comparison of silk dyed samples in relation to hue comparison to original color of vegetable waste matters

\begin{tabular}{|c|c|c|c|c|c|c|}
\hline $\begin{array}{l}\text { Sr. } \\
\text { No. }\end{array}$ & $\begin{array}{c}\text { Vegetable } \\
\text { kitchen } \\
\text { waste } \\
\text { matter } \\
\text { used as dye } \\
\text { source }\end{array}$ & $\begin{array}{c}\text { Original } \\
\text { color of } \\
\text { vegetable } \\
\text { waste } \\
\text { matter }\end{array}$ & $\begin{array}{c}\text { Fabric } \\
\text { samples } \\
\text { dyed without } \\
\text { mordant } \\
\text { using } \\
\text { conventional } \\
\text { (exhaust) } \\
\text { dyeing } \\
\text { method }\end{array}$ & $\begin{array}{c}\text { Fabric } \\
\text { samples } \\
\text { dyed } \\
\text { without } \\
\text { mordant } \\
\text { using } \\
\text { microwave } \\
\text { method }\end{array}$ & $\begin{array}{c}\text { Fabric } \\
\text { samples } \\
\text { dyed with } \\
\text { mordant } \\
\text { using } \\
\text { conventional } \\
\text { (exhaust) } \\
\text { dyeing } \\
\text { method }\end{array}$ & $\begin{array}{c}\text { Fabric } \\
\text { samples } \\
\text { dyed with } \\
\text { mordant } \\
\text { using } \\
\text { microwave } \\
\text { method }\end{array}$ \\
\hline 1 & $\begin{array}{l}\text { Mango } \\
\text { peels }\end{array}$ & $\begin{array}{l}\text { Yellow } \\
\text { orange }\end{array}$ & $\begin{array}{r}\text { Sa1 } \\
\text { (Yel } \\
\text { oran }\end{array}$ & $\begin{array}{l}\text { Same } \\
\text { (Yellow } \\
\text { orange) }\end{array}$ & $\begin{array}{r}\mathrm{S} \\
(\mathrm{Ye} \\
\text { orat }\end{array}$ & $\begin{array}{c}\text { Same } \\
\text { (Yellow } \\
\text { orange) }\end{array}$ \\
\hline 2 & $\begin{array}{c}\text { Roasted } \\
\text { chana peels }\end{array}$ & $\begin{array}{l}\text { Dark } \\
\text { brown }\end{array}$ & $\begin{array}{l}\text { Similar } \\
\text { (reddish } \\
\text { brown) }\end{array}$ & $\begin{array}{c}\text { Similar } \\
\text { (yellowis } \\
\text { h brown) }\end{array}$ & $\begin{array}{l}\text { ilar } \\
\text { dish } \\
\text { n) }\end{array}$ & $\begin{array}{c}\text { Similar } \\
\text { (yellowis } \\
\text { h brown) }\end{array}$ \\
\hline 3 & $\begin{array}{l}\text { Red apple } \\
\text { peels }\end{array}$ & Red & $\begin{array}{l}\text { Different } \\
\text { (light } \\
\text { brown) }\end{array}$ & $\begin{array}{l}\text { Different } \\
\text { (light } \\
\text { brown) }\end{array}$ & $\begin{array}{l}\text { Different } \\
\text { (light } \\
\text { brown) }\end{array}$ & $\begin{array}{l}\text { Different } \\
\text { (light } \\
\text { brown) }\end{array}$ \\
\hline 4 & $\begin{array}{c}\text { Green } \\
\text { peas pod }\end{array}$ & $\begin{array}{l}\text { Light } \\
\text { green }\end{array}$ & $\begin{array}{l}\text { Different } \\
\text { (light } \\
\text { golden } \\
\text { brown) }\end{array}$ & $\begin{array}{l}\text { Same } \\
\text { (light } \\
\text { green) }\end{array}$ & $\begin{array}{l}\text { Different } \\
\text { (light } \\
\text { golden } \\
\text { brown) }\end{array}$ & $\begin{array}{l}\text { Same } \\
\text { (light } \\
\text { green) }\end{array}$ \\
\hline 5 & $\begin{array}{l}\text { Red carrot } \\
\text { peels }\end{array}$ & Light pink & $\begin{array}{l}\text { Different } \\
\text { (pale }\end{array}$ & $\begin{array}{c}\text { Similar } \\
\text { (light }\end{array}$ & $\begin{array}{l}\text { Different } \\
\text { (pale }\end{array}$ & $\begin{array}{l}\text { Similar } \\
\text { (orange) }\end{array}$ \\
\hline
\end{tabular}




\begin{tabular}{|c|c|c|c|c|c|c|}
\hline 6 & $\begin{array}{c}\text { Fenugree } \\
\text { k stems }\end{array}$ & Green & $\begin{array}{c}\text { Similar } \\
\text { (yellowish } \\
\text { green) }\end{array}$ & $\begin{array}{c}\text { Similar } \\
\text { (light } \\
\text { green) }\end{array}$ & $\begin{array}{c}\text { Similar } \\
\text { (yellowish } \\
\text { green) }\end{array}$ & $\begin{array}{c}\text { Similar } \\
\text { (light } \\
\text { green) }\end{array}$ \\
\hline 7 & $\begin{array}{c}\text { Tulsi } \\
\text { stems }\end{array}$ & $\begin{array}{c}\text { Olive } \\
\text { green }\end{array}$ & $\begin{array}{c}\text { Same } \\
\text { (olive green) }\end{array}$ & $\begin{array}{c}\text { Same } \\
\text { (olive } \\
\text { green) }\end{array}$ & $\begin{array}{c}\text { Similar } \\
\text { (dark } \\
\text { green) }\end{array}$ & $\begin{array}{c}\text { Same } \\
\text { (olive } \\
\text { green) }\end{array}$ \\
\hline 8 & $\begin{array}{c}\text { Cucumbe } \\
\text { r peels }\end{array}$ & $\begin{array}{c}\text { Whitish } \\
\text { light green }\end{array}$ & $\begin{array}{c}\text { Similar } \\
\text { (light green) }\end{array}$ & $\begin{array}{c}\text { Same } \\
\text { (Whitish } \\
\text { light green) }\end{array}$ & $\begin{array}{c}\text { Similar } \\
\text { (light green) }\end{array}$ & $\begin{array}{c}\text { Similar } \\
\text { (light } \\
\text { green) }\end{array}$ \\
\hline
\end{tabular}

From the table it is observed that cotton fabric samples dyed using vegetable kitchen waste matter with andwithout using mordant harda by microwave method has given same color hue with compare to original hue of vegetable matter whereas conventional (exhaust) method with andwithout using mordant harda has given different color hue with compare to original hue of vegetable matter.

\section{Fibre Identification Tests}

The vertical yarns are the warp yarns and are represented as Set A.

The horizontal yarns are the weft yarns and are represented as Set B.

Table 7Burning test of Fabric A

\begin{tabular}{|c|l|l|}
\hline TEST & \multicolumn{1}{|c|}{ SET A } & \multicolumn{1}{|c|}{ SET B } \\
\hline $\begin{array}{c}\text { Approachin } \\
\text { g the flame }\end{array}$ & $\begin{array}{l}\text { Fibers } \\
\text { scorch and } \\
\text { ignite easily }\end{array}$ & $\begin{array}{l}\text { Fibers } \\
\text { scorch and } \\
\text { ignite easily }\end{array}$ \\
\hline $\begin{array}{c}\text { In the } \\
\text { flame }\end{array}$ & $\begin{array}{l}\text { Fibers } \\
\text { burn } \\
\text { quickly } \\
\text { with yellow } \\
\text { flame }\end{array}$ & $\begin{array}{l}\text { Fibers } \\
\text { burn } \\
\text { quickly } \\
\text { with yellow } \\
\text { flame }\end{array}$ \\
\hline $\begin{array}{l}\text { After } \\
\text { removal from } \\
\text { the flame }\end{array}$ & $\begin{array}{l}\text { Fibers } \\
\text { continue to } \\
\text { burn with } \\
\text { an after } \\
\text { glow }\end{array}$ & $\begin{array}{l}\text { Fibers } \\
\text { continue to } \\
\text { burn with } \\
\text { an after } \\
\text { glow }\end{array}$ \\
\hline Odour & $\begin{array}{l}\text { Prominen } \\
\text { t smell of } \\
\text { burning } \\
\text { paper }\end{array}$ & $\begin{array}{l}\text { Prominen } \\
\text { smell of } \\
\text { burning } \\
\text { paper }\end{array}$ \\
\hline Residue & $\begin{array}{l}\text { Light, } \\
\text { feathery, } \\
\text { gray, } \\
\text { crushable } \\
\text { ash }\end{array}$ & $\begin{array}{l}\text { Light, } \\
\text { feathery, } \\
\text { gray, } \\
\text { crushable } \\
\text { ash }\end{array}$ \\
\hline
\end{tabular}

In the burning test both fiber set $\mathrm{A}$ and set $\mathrm{B}$ burns readily producing a light, feathery ash that smells like burning paper so the fabric is cellulosic in nature.

Table 8 Microscopic test of Fabric $A$

\begin{tabular}{|c|c|}
\hline SET A & SET B \\
\hline Under & Under \\
\hline microscopic test, fiber & microscopic test fiber \\
\hline show: Flat ribbon like & show: Flat ribbon like \\
\hline structure & structure \\
\hline blutions or & or twist. \\
\hline Lumen is being visible & Lumen is being \\
\hline cervals. & lar interval \\
\hline fibers may be cotton & fibers may be cotton. \\
\hline
\end{tabular}

Set A: Cotton fiber

Set B: Cotton fiber
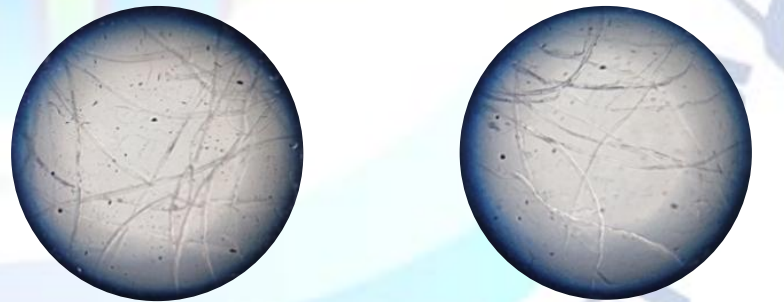

Plate 1 Microscopic structure of cotton

Table 9 Chemical solubility test of fabric $A$

\begin{tabular}{|c|c|c|}
\hline$T^{\text {REAGEN }}$ & SET A & SET B \\
\hline $\begin{array}{c}\text { Dil } \\
\mathrm{H}_{2} \mathrm{SO}_{4}\end{array}$ & $\begin{array}{c}\text { No } \\
\text { reaction }\end{array}$ & $\begin{array}{l}\text { No } \\
\text { reaction }\end{array}$ \\
\hline $\begin{array}{c}\text { Conc. } \\
\mathrm{H}_{2} \mathrm{SO}_{4}\end{array}$ & $\begin{array}{l}\text { Disintegrat } \\
\text { es and } \\
\text { dissolves }\end{array}$ & $\begin{array}{l}\text { Disintegrat } \\
\text { es and } \\
\text { dissolves }\end{array}$ \\
\hline $\begin{array}{r}10 \% \\
\mathrm{NaOH}\end{array}$ & $\begin{array}{l}\text { Swells } \\
\text { slightly }\end{array}$ & $\begin{array}{l}\text { Swells } \\
\text { slightly }\end{array}$ \\
\hline $\begin{array}{l}10 \% \\
\text { NaOH after } \\
\text { heating }\end{array}$ & $\begin{array}{l}\text { Swells } \\
\text { slightly }\end{array}$ & $\begin{array}{l}\text { Swells } \\
\text { slightly }\end{array}$ \\
\hline $\begin{array}{cc}45 & \% \\
\mathrm{NaOH} & \\
\end{array}$ & $\begin{array}{l}\text { Opens u } \\
\text { and swells }\end{array}$ & $\begin{array}{l}\text { Opens u } \\
\text { and swells }\end{array}$ \\
\hline
\end{tabular}




\begin{tabular}{|c|l|l|}
\hline $\begin{array}{c}45 \% \\
\mathrm{NaOH} \text { after } \\
\text { heating }\end{array}$ & $\begin{array}{l}\text { Swells, } \\
\text { yellow mass } \\
\text { formation }\end{array}$ & $\begin{array}{l}\text { Swells, } \\
\text { yellow mass } \\
\text { formation }\end{array}$ \\
\hline Acetone & $\begin{array}{l}\text { No } \\
\text { reaction }\end{array}$ & $\begin{array}{c}\text { No } \\
\text { reaction }\end{array}$ \\
\hline
\end{tabular}

Table 10 Burning test of fabric $B$

\begin{tabular}{|c|l|l|}
\hline TEST & SET A fuses & \multicolumn{1}{|c|}{ FET B B fuses } \\
\hline $\begin{array}{c}\text { Approachi } \\
\text { ng the flame }\end{array}$ & $\begin{array}{l}\text { Fibers furs away } \\
\text { and curls away } \\
\text { from flame }\end{array}$ & $\begin{array}{l}\text { and curls away } \\
\text { from flame }\end{array}$ \\
\hline $\begin{array}{c}\text { In the } \\
\text { flame }\end{array}$ & $\begin{array}{l}\text { Fibers burns } \\
\text { slowly with some } \\
\text { melting }\end{array}$ & $\begin{array}{l}\text { Fibers burns } \\
\text { slowly with some } \\
\text { melting }\end{array}$ \\
\hline $\begin{array}{l}\text { After } \\
\text { removal } \\
\text { from the } \\
\text { flame }\end{array}$ & $\begin{array}{l}\text { Fibers burns } \\
\text { very slowly, } \\
\text { self-extinguishe } \\
\text { s }\end{array}$ & $\begin{array}{l}\text { Fibers burns } \\
\text { very slowly, } \\
\text { self-extinguishe } \\
\text { s }\end{array}$ \\
\hline Odour & $\begin{array}{l}\text { Prominent } \\
\text { smell of burning } \\
\text { hair. }\end{array}$ & $\begin{array}{l}\text { Prominent } \\
\text { smell of burning } \\
\text { hair. }\end{array}$ \\
\hline Residue & $\begin{array}{l}\text { Round, black } \\
\text { bead, brittle, } \\
\text { crushes easily }\end{array}$ & $\begin{array}{l}\text { Round, black } \\
\text { bead, brittle, } \\
\text { crushes easily }\end{array}$ \\
\hline
\end{tabular}

In the burning test both fiber set $\mathrm{A}$ and set $\mathrm{B}$ burns slowly with melting, self-extinguishes, brittle ash that smells like burning hair so the fabric is proteinic in nature.

\section{v. CONCLUSION}

The results fulfilling the required objectives of the study helped us in conferring that vegetable kitchen waste material could be effectively used as sustainable dyeing agents with moderately good results. From the different vegetable kitchen waste used most preferred result was given by fabric samples that were dyed with fenugreek stems, tulsi stems, mango peels, red spinach stems, and cauliflower leaves in terms of depth of shade and hue.

The present results have demonstrated that the affinity of vegetable kitchen waste material as a source of natural coloring agents for dyeing proteinic silk fabric is higher than cellulosic cotton fabric by using both conventional and microwave assisted dyeing. The present work shows that, depth of the shade of coloring material was increased because of the use of mordant Harda and Pomegranate rind. From the results, it is observed that pomegranate rind is best suited for silk fabric as mordant while harda is more suited for cotton fabric.
The study revealed that microwave-assisted extraction (MAE) of vegetable kitchen waste is more efficient as compared to conventional (Exhaust) extraction method because the color of the original kitchen waste matter is retained in the extracted liquor. MAE provided high extraction efficiency in a short 6 minutes time whereas in conventional extraction method 1 hour is required. The liquor used in MAE is also very less compared to conventional extraction $200 \mathrm{ml}$ and $1: 15 \mathrm{ml}$ respectively. With that, MAE uses less energy as well improved yield of natural colorant was obtained compared to conventional extraction.

In the dyeing process conventional method has given good results in terms of depth of shade but not able to give various hues of colors because on all the fabric samples brown or green colors were observed which may be due to oxidation of colouring component whereas microwave-assisted dyeing (MAD) was able to retain the original color of vegetable waste matter thus giving the colours close to the original source. Compared to conventional dyeing, MAD has shown good results in easy production of desired shades with quick dyeing which required only 6 minutes completing the dyeing in turn less power consumption whereas in conventional dyeing it required 1 hour.

It could be concluded that the microwave-assisted extraction and dyeing technique is highly effective in terms of saving the processing time, energy, and resources. Other additional features about microwave is that it is cheaper, more economical, energy saving and thereby eco-friendly. Researcher believes that the results obtained from this study are interesting for small-scale application especially in developing countries like India in the long run due to the production of a natural dye as an inexpensive source from vegetable kitchen waste as by-products.

From the result, it could be concluded that there is need to make the consumers aware about natural dyeing which was accomplished to some extent through this research. Consumers believed as expressed in the opinion survey that this research idea is excellent and will help in reducing waste and with that they are willing to buy the textile products dyed using vegetable kitchen waste.

\section{REFERENCES}

[1] M. Daniel, S.D. Bhattacharya, Arun Arya, V.M. Raole (2013) Natural dyes: scope and challenges. 
A.Shrivastava, E.M. Dedhia,"Extraction and dyeing method for natural dyes", pp 75-76.

[2] https://economictimes.indiatimes.com/news/ economy/agriculture/india-wastes-fruits-andvegetables-worth-rs-13300-crore-every-year-e merson-study/articleshow/26523928.cms

[3] https://microbewiki.kenyon.edu/index.php/K itchen_waste\#: :text=Kitchen\%20waste\%20is \%20defined $\%$ 20as, daily $\% 20 \mathrm{in} \% 20$ highly $\% 20 \mathrm{p}$ opulated $\% 20$ areas.

[4] Jumiang Tang et al (2002),Vankar. (2007). "Non-Conventional Dyeing Technologies", Ch.2. pp. 16-35.[Online]. Available: https://shodhganga.inflibnet.ac.in/bitstream/1060 3/32154/7/07_chapter2.pdf

[5] Maria Llompart, Thierry Dagnac. (2019).

"Microwave-Assisted Extraction".[Online].

Available:https://www.sciencedirect.com/topics/ch emistry/microwave-assisted-extraction

[6] S.Mitra, Dr. A.Kumar, R. Choudhury (2015, May). Dyeing of silk with raw natural colours. Colourage. LXII(5), pp. 35-36.

[7] P.D. Patil, Dr. C.R. Rao Dr. A.I. Wasif(2012, October). Revival of natural dyes: smart use of biodiversity. Colourage. LIX(10), p. 33.

[8] M. Rais and A. Sheoran (2015). Scope of Supply Chain Management in Fruits and Vegetables in India. Journal of Food $J$ Processing \& Technology[Online].

6(3).Available:https://www.longdom.org/open-acce ss/scope-of-supply-chain-management-in-fruits-an d-vegetables-in-india-2157-7110-1000427.pdf

[9] S. Gala, Sumarno and Mahfud. (2016, April). Microwave-assisted Extraction of Natural Dyes from Coleus atropurpureus Leaves: The Effect of Solvent. European Journal of Biotechnology and Bioscience[Online]. $\quad 4(4), \quad$ pp. 1-5.Available:https://www.matec-conferences.org/ articles/matecconf/pdf/2018/15/matecconf_rsce2 018_06011.pdf

[10] M.D. Teli, J. Sheikh and R. Tibrewal (2013). Microwave assisted extraction of Natural Dyes and Natural Mordants vis-a-vis dyeings. Asian Dyer[Online]. 10, pp 32-38.Available:https://www.researchgate.net/pub lication/286273934_Microwave_assisted_extraction of_Natural_Dyes_and_Natural_Mordants_vis-a-vis_ dyeings

[11] 